\title{
Corporate Ownership Around the World
}

\section{Citation}

La Porta, Rafael, Florencio Lopez-De-Silanes, and Andrei Shleifer. 1999. Corporate Ownership Around the World. The Journal of Finance 54, no. 2: 471-517. Portico. doi:10.1111/0022-1082.00115.

\section{Published Version}

doi:10.1111/0022-1082.00115

\section{Permanent link}

http://nrs.harvard.edu/urn-3:HUL.InstRepos:30747162

\section{Terms of Use}

This article was downloaded from Harvard University's DASH repository, and is made available under the terms and conditions applicable to Other Posted Material, as set forth at http:// nrs.harvard.edu/urn-3:HUL.InstRepos:dash.current.terms-of-use\#LAA

\section{Share Your Story}

The Harvard community has made this article openly available.

Please share how this access benefits you. Submit a story.

Accessibility 
NBER WORKING PAPER SERIES

\title{
CORPORATE OWNERSHIP AROUND THE WORLD
}

\author{
Rafael La Porta \\ Florencio Lopez-de-Silanes \\ Andrei Shleifer
}

\author{
Working Paper 6625 \\ http://www.nber.org/papers/w6625 \\ NATIONAL BUREAU OF ECONOMIC RESEARCH \\ 1050 Massachusetts Avenue \\ Cambridge, MA 02138 \\ June 1998
}

We are grateful to Alexander Aganin, Carlos Berdejo-Izquierdo, David Grossman, Bernardo LopezMorton, Tatiana Nenova, Ekaterina Trizlova, and David Witkin for help with assembling the data, to Mihir Desai, Oliver Hart, Louis Kaplow, and Robert Vishny for advice, and the National Science Foundation for financial support to the NBER. Any opinions expressed are those of the author and not those of the National Bureau of Economic Research.

(c) 1998 by Rafael La Porta, Florencio Lopez-de-Silanes, and Andrei Shleifer. All rights reserved. Short sections of text, not to exceed two paragraphs, may be quoted without explicit permission provided that full credit, including $(\mathcal{O}$ notice, is given to the source. 
Corporate Ownership Around the World

Rafael La Porta, Florencio Lopez-de-Silanes, and Andrei Shleifer

NBER Working Paper No. 6625

June 1998

JEL No. G30, G32

\begin{abstract}
We present data on ownership structures of large corporations in 27 wealthy economies, making an effort to identify ultimate controlling shareholders of these firms. We find that, except in economies with very good shareholder protection, relatively few of these firms are widely-held, in contrast to the Berle and Means image of ownership of the modern corporation. Rather, these firms are typically controlled by families or the State. Equity control by financial institutions or other widely-held corporations is less common. The controlling shareholders typically have the power over firms significantly in excess of their cash flow rights, primarily through the use of pyramids and participation in management. The results suggest that the principal agency problem in large corporations around the world is that of restricting expropriation of minority shareholders by the controlling shareholders, rather than that of restricting empire building by professional managers unaccountable to shareholders.
\end{abstract}

Rafael La Porta

Department of Economics

Harvard University

Cambridge, MA 02138

and NBER

Andrei Shleifer

Department of Economics

Littauer 315

Harvard University

Cambridge, MA 02138

and NBER

ashleifer@harvard.edu
Florencio Lopez-de-Silanes

Kennedy School of Government

Harvard University

79 JFK Street

Cambridge, MA 02138

and NBER

f_lopezdesilanes@harvard.edu 
1. Introduction.

In their 1932 classic, "The Modern Corporation and Private Property," Adolph Berle and Gardiner Means called attention to the prevalence of the widely-held corporations in the United States, in which ownership of capital was dispersed between small shareholders, yet control was concentrated in the hands of managers. For at least two generations, their book fixed the image of the modern corporation as one run by professional managers unaccountable to shareholders. The book has stimulated an enormous "managerialist" literature on the objectives of such managers, including important work of Baumol (1959), Marris (1964), Penrose (1959), and Williamson (1964), as well as Galbraith's (1967) popular and extremely influential account. More recently, the modern field of corporate finance has developed around the same image of a widely-held corporation, as can be seen in the central contributions of Jensen and Meckling (1976) or Grossman and Hart (1980). The Berle and Means image has clearly stuck.

In recent years, several studies have begun to question the empirical validity of this image. Eisenberg (1976), Demsetz (1983), Demsetz and Lehn (1985), Shleifer and Vishny (1986), and Morck, Shleifer and Vishny (1988) have shown that, even among the largest US firms, there is a modest concentration of ownership. Holderness and Sheehan (1988) have found several hundred publicly-traded firms with majority (>51\%) shareholders in the US. Studies of other rich countries that followed discovered more significant concentration of ownership in Germany (Franks and Mayer 1994, Gorton and Schmid 1996), Japan (Prowse 1992, Berglof and Perotti 1994), Italy (Barca 1995), and seven OECD countries (European Corporate Governance Network 1997). In developing economies, ownership is even more concentrated (La Porta et al. 1998). This research suggests not only that, in many countries, large corporations have large 
shareholders, but also that these shareholders are active in corporate governance, in contrast to the Berle and Means idea that managers are unaccountable (e.g., Kang and Shivdasani 1995, Yafeh and Yosha 1996). ${ }^{2}$

Thanks to this research, the Berle and Means image of a modern corporation has begun to show some wear. Still, we have relatively little systematic evidence on the ownership patterns of large publicly traded firms in different countries, and lack a comparative perspective on the relevance of the Berle and Means description of the firm. This paper attempts to provide some such evidence. Specifically, we look at the ownership structures of the twenty largest publicly traded firms in each of the 27 (generally richest) economies, as well as of some smaller firms so that we can keep size constant across countries. We focus on the largest firms in the richest economies precisely because, for these firms, the likelihood of widely-dispersed ownership is the greatest (this is indeed the case). Our principal contribution is to find wherever possible the identities of the ultimate owners of capital and of voting rights in firms, so when shares in a firm are owned by another company, as is often the case, we examine the ownership of that company, and so $\mathrm{on}^{3}$. For most countries, this is the only way to understand the relationship between ownership and control. These data enable us to address, in a comparative perspective, four broad questions related to the Berle and Means thesis.

First, how common are widely held firms in different countries, as opposed to firms that

\footnotetext{
${ }^{2}$ There is a parallel theoretical literature on the role of large shareholders, including Shleifer and Vishny (1986), Stulz (1988), Grossman and Hart (1988), Harris and Raviv (1988), Bebchuk (1994), and Berkart, Gromb, Panunzi $(1997,1998)$.

${ }^{3}$ La Porta, Lopez-de-Silanes, Shleifer, and Vishny (1998) examine first level ownership of the 10 largest publicly traded firms in 49 countries, but do not attempt to understand who owns the immediate owners of the firms in their sample. This paper attempts to deal with this issue.
} 
have owners with significant voting rights? Second, to the extent that firms have significant owners, who are they? Are they families, the government, financial institutions, or other -possibly widely held -- firms? How often do banks control companies -- a big issue in corporate finance in light of the extensive discussion of the German corporate governance model? Third, how do these owners exercise their power? Do they use shares with superior voting rights that enable them to exercise control with only limited ownership of capital? Alternatively, do they create complicated cross-ownership patterns to reduce the threat to their control? Or do they build pyramids, whereby they control firms through a chain of companies -- another form of separating ownership of capital and control? By answering these questions empirically, we hope to provide a comprehensive description of ownership patterns of large firms in rich countries.

The fourth question we address is: what explains the differences between countries in their ownership patterns? Why, for example, is the Berle and Means image of a widely held firm so much more descriptive of the US of Mexico or Italy? Our earlier work (La Porta et al. 1997, 1998) suggests that the widely-held Berle and Means corporation should be more common in countries with good legal protection of minority shareholders (which are often rich common law countries). In these countries, minority shareholders are willing to pay higher prices for shares, knowing that the law protects their investment from expropriation by the controlling shareholders even when they cannot directly influence corporate decisions. When minority shareholders pay more for the shares, controlling shareholders are more willing to raise equity finance, diversify, and more generally reduce their ownership stakes. Moreover, with good shareholder protection, controlling shareholders do not need to fear being expropriated themselves in the event that they ever lose control, and so again might be willing to cut their stakes. In this paper, we examine 
whether these theoretical predictions hold up empirically.

Relatedly, we evaluate the relationship between shareholder protection and the incidence of various control arrangements, including differential voting rights and pyramids. The theory in this area is not completely developed, but some articles do help us to think about the data. Grossman and Hart (1988) and Harris and Raviv (1988) suggest that deviations from one-shareone-vote should be larger when private benefits of control are higher, which must be the case in countries with poorer shareholder protection. Wolfenzohn (1998) argues that pyramids as well should be more common in countries with poor shareholder protection, because it is easier for controlling shareholders there to make minority shareholders in existing firms pay for starting up new firms as partial subsidiaries without fully sharing with these minorities the benefits of a new venture. Pyramids and multiple classes of stock are of course two different ways of separating cash flow and control rights in firms.

A brief summary of our main conclusions is presented in Table 1 . We find that the Berle and Means corporation is far from universal, and is quite rare on some definitions of control. Similarly, the so-called German model of bank control through equity is uncommon. Instead, controlling shareholders -- usually the State or families -- are present in most large companies. These shareholders have control rights in firms in excess of their cash flow rights, largely through the use of pyramids, but they also participate in management. The power of these controlling shareholders is not evidently checked by other large shareholders. The results suggest that the theory of corporate finance relevant for most countries should focus on the incentives and capabilities of controlling shareholders with large equity stakes to pursue strategies that benefit them at the expense of the minority shareholders. Unlike in the case of Berle and Means 
managers with limited ownership interests, the problem of expropriation of minorities becomes much more central than that of empire building.

The next section of the paper describes our data, and presents a number of examples of ownership patterns in particular companies. Section 3 presents the basic results on the incidence of various ownership structures around the world. Section 4 concludes.

2. Data.

\section{Construction of the Database}

This paper is based on a new database of ownership structures of companies from 27 countries. As we detail below, the data on corporate ownership are often difficult to assemble, and this limitation determines many of the choices we make. We generally use the richest countries based on 1993 per capita income, but exclude a number of them that do not have significant stock markets (e.g., Kuwait, United Arab Emirates, Saudi Arabia) ${ }^{4}$. For each country, we collect two samples of firms. The first sample consists of the top 20 firms ranked by market capitalization of common equity at the end of 1995 (with some exceptions detailed below). This sample runs into the objection that the largest companies in some countries are much larger than the largest companies in other countries. This is a particularly serious issue for a study of ownership because larger companies presumably have less concentrated ownership, and hence we should be careful that our measures of block ownership do not simply proxy for size. Accordingly, the second sample collects, whenever possible, the smallest 10 firms in each

${ }^{4}$ If we included the poorer countries, the incidence of family and State control would be only higher, and the prevalence of widely held firms significantly lower. 
country with market capitalization of common equity of at least $\$ 500$ million at the end of 1995 . We call the first sample "large firms" and the second sample "medium firms." For countries with small stock markets, the two samples intersect. Moreover, for 6 countries (Argentina, Austria, Ireland, New Zealand, Greece, and Portugal) we do not have 10 publicly traded firms with capitalizations above $\$ 500$ million. Overall, we have 540 large firms in the large firm sample, and a total of 691 different firms (out of a possible maximum of 810 ). ${ }^{5}$

There are a few further restrictions on these samples of companies. First, for both the large and the medium samples, we exclude all affiliates of foreign firms. A firm is defined as an affiliate of a foreign company if at least 50 percent of its votes are directly controlled by a single foreign corporate owner. In addition, we exclude banks and utilities from the sample of medium firms, to prevent the domination of this sample by these two industries. Finally, by construction, neither sample includes companies that are owned either wholly privately or wholly by the government, and therefore not listed. The last restriction, of course, biases our results toward finding fewer firms with significant government and family ownership than actually exist.

As a rule, our companies come from WorldScope database. In four countries for which WorldScope coverage is limited (Argentina, Israel, Mexico, and the Netherlands), we use other sources (see Appendix A for data sources). We generally rely on annual reports, 20-F filings for companies with American Depositary Receipts (ADRs), proxy statements, and -- for several countries -- country-specific books that detail ownership structures of their companies. We also

${ }^{5}$ Note that medium firms are, on average, larger in countries with smaller stock markets than in countries with larger stock markets, since the latter countries have more firms with capitalizations just above $\$ 500$ million. In the medium firm sample, therefore, the size bias is toward finding less ownership concentration in countries with poor shareholder protection. 
found the INTERNET to be very useful because many individual companies (e.g., in Scandinavia), as well as institutions (e.g., the Paris Bourse and The Financial Times) have Websites that contain information on ownership structures. Virtually all of our data are for 1996 and 1995 , though we have a few observations where the data come from the earlier years, and a few from 1997. Because ownership patterns tend to be relatively stable, the fact that the ownership data do not all come from the same year is not a big problem.

For several countries, our standard procedures do not work because disclosure is so limited. For Greece and Mexico, we could not work with the 20 largest firms because we did not have enough ownership data. For Greece, we take the 20 largest corporations for which we could find ownership data (mostly in Bloomberg). For Mexico, we take the 20 largest firms that have ADRs. For Israel, we rely almost entirely on Lexis/Nexis and INTERNET sources. For Korea, different sources offer conflicting information on corporate ownership structures of chaebols. We were advised by Korean scholars that the best source for chaebols contains information as of 1984, so we use the more stale but reliable data.

To describe control of companies, we generally look for all shareholders who control over 10 percent of the votes. The cutoff of 10 percent is used because (1) it provides a significant threshold of votes, and (2) most countries mandate disclosure of 10 percent, and usually even lower, ownership stakes. For most countries and companies, we have some information on smaller shareholdings, but generally focus only on shareholders who control over 10 percent of the votes. In many cases, the principal shareholders in our firms are themselves corporate entities and financial institutions. In all these cases, we try to find the major shareholders in these entities, then the major shareholders in the major shareholders, and so on, until we find the 
ultimate controllers of the votes. In many cases, the ultimate controller is the State, a widely held financial institution, or a widely held corporation. In other cases, it is an individual or a family. We do not attempt to get inside families, and assume that every family owns and votes its shares collectively.

\section{Definitions of Variables}

We ask whether firms have substantial owners. We do not try to measure ownership concentration, because a theoretically appropriate measure requires a model of the interactions between large shareholders, which we do not have. Rather, we try to define owners in a variety of ways, summarized in Table 2 and discussed in this subsection. In the following subsection, we illustrate these definitions using several companies from our sample.

Our definitions of ownership rely on voting rights rather than cash flow rights. Recall that Berle and Means wanted to know who controls the modern corporation: shareholders or managers. We as well want to know whether corporations have shareholders with substantial voting rights, either directly or through a chain of holdings. This idea motivates our definitions.

We divide firms into widely held and those with ultimate owners. We allow for five types of ultimate owners: 1) a family or an individual, 2) the State, 3) a widely held financial institution such as a bank or an insurance company, 4) a widely held corporation, or 5) miscellaneous, such as a cooperative, a voting trust, or a group with no single controlling investor. State control is a separate category because it is a form of concentrated ownership in which the State uses firms to pursue political objectives, while the public pays for the losses (Shleifer and Vishny 1994). We also give widely held corporations and widely held financial institutions separate categories as 
owners because it is unclear whether firms they control should be thought of as widely-held or having an ultimate owner. A firm controlled by a widely-held corporation or financial institution can be thought of as widely-held since the management of the controlling entity is not itself accountable to an ultimate owner, but also as accountable to that management. For these reasons (and because bank ownership is of independent interest), we keep these categories separate.

As a first cut, we say that a corporation has a controlling shareholder (ultimate owner) if this shareholder's direct and indirect voting rights in the firm exceed 20 percent. A shareholder has $\mathrm{x} \%$ indirect control over firm $\mathrm{A}$ if: (1) it controls directly firm B which, in turn, directly controls $\mathrm{x} \%$ of the votes in firm $\mathrm{A}$; or (2) it controls directly firm $\mathrm{C}$ which in turn controls firm $\mathrm{B}$ (or a sequence of firms leading to firm B each of which has control over the next one, i.e., they form a control chain), which directly controls $x \%$ of the votes in firm A. Table 2 provides a more precise definition. The idea behind using 20 percent of the votes is that this is usually enough to have effective control of a firm. Indeed, below we present evidence that, in the majority of cases, our ultimate owners are also part of the management of the firm.

In the simplest case, each sample firm would have an ultimate owner of the above five types. There may, alternatively, be a legal entity that has over 20 percent voting rights in our sample firm, and that itself has a shareholder with over 20 percent of the votes, and so on. We classify all firms that do not have such a 20 percent chain of voting rights as widely-held, and firms without such a chain as firms with owners. On this definition, if company B has 23 percent of the votes in company $\mathrm{A}$, and individual $\mathrm{C}$ has 19 percent of the votes in $\mathrm{B}$, we still call $\mathrm{A}$ controlled by a widely-held corporation (unless $\mathrm{C}$ has additional control in $\mathrm{A}$ through another chain -- see the discussion of Korea below). In addition to the definition of ultimate owners 
using this 20 percent of votes rule, we consider a second definition that relies on a chain of over 10 percent of voting rights.

The above definitions give us a reasonably conservative way to answer the question: do firms have shareholders with a substantial amount of control, or ultimate owners? But this is not the only interesting aspect of ownership. To evaluate the potential for agency problems between ultimate owners and minority shareholders, we also want to know whether the cash flow ownership rights of the controlling shareholders are substantially different from their voting rights. One way in which the ultimate owners can reduce their ownership below their control rights is by using shares with superior voting rights; another way is to organize the ownership structure of the firm in a pyramid. Finally, the ultimate owners might wish to solidify their control through cross-shareholdings: having the firm own shares in its shareholders.

We describe the role of multiple classes of shares in the simplest possible way. For each firm in the sample, we ask what is the minimum percentage of its capital at par value that the immediate shareholder (who might be different from the ultimate owner) needs to own to have 20 percent of the voting rights under the existing structure of share types of that firm (as opposed to what might be allowed by law). For example, if a firm has 50 percent of its capital in the form of shares that have 100 percent of voting rights, and 50 percent in the form of non-voting shares, we would say that a shareholder must own at least 10 percent of capital (in the form of the first kind of shares) to have 20 percent of the votes. Note that we are only computing this measure for the firms in the sample; we do not capture a deviation from one-share-one-vote if a publicly held corporate shareholder in our sample firm itself has multiple classes of stock.

We say that a firm's ownership structure is a pyramid (on the 20 percent definition) if: 
(1) it has an ultimate owner, and (2) there is at least one publicly traded company between it and the ultimate owner in the chain of 20 percent voting rights. Thus if a publicly traded firm B has 43 percent of the votes in a sample firm $\mathrm{A}$, and an individual $\mathrm{C}$ has 27 percent of the votes in

firm B, we would say that C controls A, and that the ownership structure is a pyramid. But if B is 100 percent owned by $\mathrm{C}$, we would still call $\mathrm{C}$ the ultimate owner, but would not call the ownership structure a pyramid. Pyramids require publicly traded intermediate companies. We also use a parallel definition of pyramids with 10 rather than 20 percent of voting rights.

We say that there is cross-shareholding by firm A from the sample if A owns any shares in its controlling shareholder or in the companies along that chain of control. So, if firm B has 20 percent of the votes in A, a publicly held firm C owns 20 percent of the votes in $\mathrm{B}$, and $\mathrm{A}$ owns 2 percent of the votes in $\mathrm{C}$, we would say that $\mathrm{C}$ is the ultimate owner of $\mathrm{A}$, that $\mathrm{A}$ is owned through a pyramid, and that there is a cross-shareholding by A. On the other hand, if, instead of A owning 2 percent in $\mathrm{C}$, it were the case that B owned 2 percent in $\mathrm{C}$, we would not call this a cross-shareholding by A because B is not a firm in our sample.

We use some further measures of ownership that are summarized in Table 2, but introduce them later as we present our findings in Section 3. First, we present some examples.

\section{Examples of Ownership Structures}

To describe the database and to illustrate our variables, we present several cases of ownership structures of individual companies, in roughly increasing order of complexity.

Begin with the United States. The three most valuable firms in the US at the end of 1995, General Electric, AT \& T, and Exxon, are all widely held. The fourth most valuable, Microsoft, 
has three large shareholders (Figure 1), who are all co-founders, Bill Gates (with 23.7 percent of the votes as well as shares), Paul Allen (with 9 percent), and Steven Ballmer (with 5 percent). We say that Microsoft has an ultimate owner on the 20 percent (as well as on the 10 percent) definition, namely Bill Gates, and is a family-owned firm. It is obviously not a pyramid, does not have cross-shareholdings, and it takes 20 percent of the capital to amass 20 percent of the votes.

The fourth most valuable company in Canada is Barrick Gold, and it has a more complex ownership structure (Figure 2). Its founder, Chairman, and CEO is Peter Munk, who is also Chairman and CEO of a holding company called Horsham, that owns 16.3 percent of votes and capital in Barrick Gold. Mr. Munk controls the publicly-traded Horsham with 79.7 percent of its votes, but only 7.3 percent of capital. Even though Munk evidently controls Barrick, we say that Barrick Gold is widely-held on the 20 percent definition of control, since Horsham only has 16.3 percent of the votes, but that it has an ultimate owner, a family, on the 10 percent definition. Since Horsham is publicly traded, we call Barrick's ownership structure a pyramid on the 10, but not the 20, percent definition. Finally, even though Horsham has multiple classes of stock, it takes 20 percent of Barrick's capital to have 20 percent of the votes, and so the company in our sample -- Barrick -- has a one-share-one-vote structure.

The next example is Hutchison Whampoa, the third most valuable company in Hong Kong (Figure 3). It is 43.9 percent controlled by Cheung Kong Holdings, which happens to be the 5th largest publicly traded company in Hong Kong and is therefore also in our sample. In turn, Li Ka Shing family owns 35 percent of Cheung Kong. Hutchison Whampoa and Cheung Kong are thus both family controlled companies, except the former is owned through a pyramid but the latter is not. Note that Li Ka Shing controls 3 of the 20 largest companies in Hong Kong 
(also the 11 th largest Hong Kong Electric Holdings), a number that we keep track of.

After the State-controlled NT \& T, Toyota Motor is the most valuable company in Japan (Figure 4). Toyota has several non-trivial shareholders, but none of them is very large. Four of these shareholders (Sakura Bank, Mitsui Fire and Marine, Mitsui T \& B, and Mitsui Life) are part of the Mitsui Group and together control 12.1 percent of both capital and votes in Toyota. This is a common situation in Japan, and we say that Toyota is widely-held on the 20 percent definition, but "miscellaneous" on the 10 percent definition, because that is where we put business groups as well as voting trusts. There are no pyramids or deviations from one-shareone-vote here, but Toyota has cross-shareholdings in firms in the Mitsui Group.

Ownership in Japanese companies is straightforward relative to that in Korean ones, as the example of Korea's second largest firm, Samsung Electronics (Figure 5), illustrates. Samsung's founder, Lee Kun-Hee controls 8.3 percent of Samsung Electronics directly. But he also controls 15 percent of Samsung Life, which controls 8.7 percent of Samsung Electronics, as well as 14.1 percent of Cheil Jedang, which controls 3.2 percent of Samsung Electronics directly but also 11.5 percent of Samsung Life. Lee Kun-Hee has additional indirect stakes in Samsung Electronics as well. Because there are no 20 percent ownership chains, we call Samsung Electronics widely-held on the 20 percent definition. But because between his direct holdings and holdings in Samsung Life Lee Kun-Hee controls over 10 percent of the votes in Samsung Electronics, it is a family-controlled firm on the 10 percent definition. It is also controlled through a pyramid on that definition because Samsung Life is publicly traded.

Finally, to illustrate the really complicated cases, we consider ownership structure of five companies from Continental Europe. We begin with Germany, where the most valuable 
company is Allianz Insurance (Figure 6). Allianz is a one-share-one-vote company with several large shareholders, of whom the largest, with a 25 percent stake, is Munich Reinsurance, the third most valuable company in Germany. However, Allianz has cross-shareholdings in most of its large shareholders, including a 25 percent stake in Munich Reinsurance (Allianz also has a 22.5 percent stake in Dresdner Bank, which has a 10 percent stake in Munich Reinsurance). Allianz presents a difficult case: one could argue that it is widely held because it controls its controlling shareholder, that it is controlled by a widely-held financial institution, or that it belongs in the "miscellaneous" category. We allocate it to the first category, while (happily) recognizing that there are only 4 such controversial cases in the sample, including Munich Reinsurance itself.

The fourth largest company in Germany is Daimler-Benz (Figure 7). It is 24.4 percent owned by Deutsche Bank, so its ultimate owner is a widely-held financial institution (the largest shareholder in Deutsche Bank is Allianz, with 5 percent). Other shareholders of Daimler Benz form an enormous pyramid, but we would not call its ownership structure a pyramid because it does not involve publicly traded firms in the control chain and does not lead to the ultimate owner. While there are other over 10 percent shareholders, and chains of shareholders, in Daimler Benz, for the purposes of most of our analysis we only look at the largest shareholder, namely Deutsche Bank. Note that, for Germany, we ignore the voting arrangements which enable Deutsche and other banks to vote the shares they hold in custody for their brokerage clients: here we only look at their own stakes.

The fourth most valuable company in Sweden is ABB (Figure 8). Like five of the top ten most valuable companies in Sweden, $\mathrm{ABB}$ is controlled by the Wallenberg family, characteristically through a pyramid of companies that have shares with differential cash flow 
and voting rights. Incentive, the 17th most valuable company in Sweden, owns 24.3 percent of capital and has 32.8 percent of the votes in ABB. The Wallenberg Group owns 32.8 percent of the capital, but has 43.1 percent of the votes in Incentive. The Wallenberg Group is a voting arrangement controlled by Investor (which has 35.7 percent of the Group's total of 43 percent of the votes in Incentive). Investor is the fifth most valuable company in Sweden, controlled by the Wallenberg Group with 41.2 percent of the votes. So here we have family control, pyramids, and deviations from one-share-one-vote. Only the extensive disclosure requirements allow us to describe ownership patterns in Sweden.

ABB is a good company to illustrate how we measure the extent of deviations from oneshare-one-vote. The company has $24,345,619$ shares with 0.1 votes per share and a par value of $50 \mathrm{SEK}$, as well as $66,819,757$ shares with 1 vote per share and a par value of 5 SEK. Here the cheapest way to buy a 20 percent voting stake is to acquire the second kind of shares only. The number of required votes is $13,850,865=.2 *\left[24,345,619^{*} .1+66,819,757\right]$, and each of these votes costs SEK 5 at par value. The par value of the firm is SEK 1,551 billion. Therefore, the cost of buying the required votes as a percentage of the total book value of the firm's capital is $[\operatorname{SEK} 5 * 13,850,864] /[\operatorname{SEK} 1,551$ billion $]=4.46$ percent. To acquire 20 percent of the votes in $\mathrm{ABB}$, one can buy only 4.46 percent of the capital, a sharp deviation from one-share-one-vote. The third most valuable company in Italy is Fiat (Figure 9). Many of its shares are controlled by a voting trust, of which the most important member is Ifi, with 14.8 percent of the capital and 22.3 percent of the votes. Another large shareholder is Ifil, with 6.1 percent of the capital and 9.2 percent of the votes. Ifi is controlled by Giovanni Agnelli and his family, who have 41.2 plus 8.75 , or 49.95 percent of the capital and 100 percent of the votes. Ifi also controls 
Ifil with 26.5 percent of the capital and 52.25 percent of the votes. So here we have family control through pyramids and voting trusts, though no evident cross-shareholdings by Fiat. The majority of Fiat's shares are ordinary, but there are a few savings shares with no voting rights. As a consequence, one can control 20 percent of Fiat's votes with 15.47 percent of its capital. The last, and possibly most complicated, example we present is Electrabel, the largest listed company in Belgium (Figure 10). Fortunately, voting and cash flow rights are the same here. One can see that 26.34 percent of Electrabel is controlled by Powerfin, the 11 th largest company in Belgium. In turn 60 percent of Powerfin is owned by Tractebel, which is the 3rd largest company in Belgium, and which also controls 16.2 percent of Electrabel directly. But who owns Tractebel? The Belgian bank, General de Belgique, owns 27.5 percent of the company directly, and also controls 8.02 percent of the votes held by Genfina. General de Belgique does not itself enter the Belgian sample because it is 49.4 percent owned by a French bank, Compagnie de Suez, and hence is defined to be a foreign affiliate. Hence, through this pyramid, Electrabel is controlled by a widely held financial institution. Tractebel, however, has an additional significant set of owners. Actually, 20 percent of its shares are owned by Electrafina, the 12th largest company in Belgium. Electrafina, in turn, is controlled with a 46.6 percent stake by Groupe Bruxelle Lambert, a holding company which is the 9th largest in Belgium. Groupe Bruxelle Lambert is in turn controlled with 49.7 percent by Pargesa, a Swisslisted holding controlled by the Belgian Frere family. Thus the Freres can also be viewed as the owners of Electrabel, except that we count only the largest ultimate owner, and hence Electrabel goes to Compagnie de Suez. There are many other relationships between the various companies in these pyramids, which are presented in Figure 10. Electrabel offers a good reason to only look 
at the largest shareholders rather than measure ownership concentration.

The above examples are not intended to prejudge the reader's opinion as to the relative frequency of widely-held versus owner-controlled firms, but rather to show how complicated ownership structures can be. In the next section, we abstract from the many subtleties of ownership and present the simple statistics on the relative frequency of different arrangements.

3. Results.

Who Owns Firms?

Tables 3A - 3D present the basic information from our sample on who the ultimate owners of firms are in different countries. We divide the 27 countries in the sample into 12 with better than median (4 and 5) shareholder protection using the scores from La Porta et al. (1998), and 15 with median and worse than median protection $(0,1,2$, and 3$)$. These scores aggregate a number of legal shareholder protections used in different countries (Table 2). The good protection subsample is dominated by common law countries, and the bad protection subsample by civil law countries. We describe average ownership patterns for each country, and then compare average patterns for the world (meaning the 27 rich countries), the good protection countries, and the bad protection countries. We have four tables because we do the 20 percent and the 10 percent chain of control calculations separately, and do each calculation for the large and the medium firm samples.

Within each country, for a given sample and a given definition of control, we classify every firm following the rules described in the previous section as one of six types: widely-held, family-controlled, state-controlled, controlled by a widely-held financial institution, controlled by 
a widely-held corporation, or miscellaneous. We then compute and report the frequency of each type of firm in each country, and take appropriate averages. The t-tests comparing groups of countries treat each country's average as one observation.

Table 3A shows that, for the sample of large firms, and using the 20 percent definition of control, 36 percent of the firms in the world are widely-held, 30 percent are family-controlled, 18 percent are state-controlled, and the remaining 15 percent are divided between the residual categories. To us, the fact that only slightly more than a third of the firms in the richest countries, selected for their large size, and using the stiff 20 percent chain definition of control are widely-held suggests that the image of the Berle and Means corporation as the dominant ownership structure in the world is misleading. It is true that, on this definition, all 20 firms in the UK, 18 out of 20 in Japan, and 16 out of 20 in the US fit the widely-held description. Still, in Argentina, Greece, Austria, Hong Kong, Portugal, Israel, or Belgium, there are hardly any widely-held firms even in this sample and on this definition. A critic might remark that most of the value of the world stock market is in the US, UK, Japan and other countries with Berle and Means firms, so who cares about Argentina or Austria? We care because to understand corporate governance in most countries in the world, to appreciate what is essential about the countries where Berle and Means corporations are common, and consequently to see how corporate governance is changing, it is important to recognize how much of an exception widely-held corporations really are.

Among corporations with owners, the principal owner types are the families and the State. The high percentage of companies with State control in this sample is not surprising given that we are sampling the largest firms, and privatization is not finished in most countries. Still, 
the facts that 70 percent of the largest traded firms in Austria, 45 percent in Singapore, and 40 percent in Israel and Italy are state-controlled is a reminder of massive post-war State ownership around the world. Indeed, the magnitude of state ownership among the largest companies would be even higher if we included firms that are entirely state-owned, and hence do not trade publicly. It is perhaps more surprising that by far the dominant form of controlling ownership in the world is not that by banks and other corporations, but rather by families.

A comparison of countries with good and poor shareholder protection shows that widelyheld firms are more common in countries with good protection: 48 percent versus 27 percent. This difference is statistically significant $(t=-1.95)$. Countries with poor shareholder protection have more of most other types of firms, including family-controlled: 34 versus 25 percent $(t=$ 1.09), and State-controlled: 22 versus 14 percent $(\mathrm{t}=1.20)$. Interestingly, firms in countries with good protection are more commonly controlled by a widely-held corporation: 8 versus 2 percent $(t=-2.38)$. These results suggest that dispersion of ownership goes together with good shareholder protection, which enables controlling shareholders to divest at attractive prices.

Table 3B presents the results for the sample of large firms using the 10 percent chain definition of control. Under this definition, only 24 percent of the large companies in rich countries are widely-held, compared to 35 percent that are family-controlled, 20 are percent statecontrolled, and 21 percent are in the three residual categories. We stress that using the 10 percent control chain to define control is not incredibly tough on the Berle and Means thesis; many people would consider 10 percent ownership of a US firms to be sufficient for control. Indeed, 90 percent of the large UK firms, 80 percent of the large US firms, and 50 percent of the large Japanese firms remain widely-held. Still, in the rich world as a whole, dispersed ownership is 
rare on this definition.

One finding of Table 3B is that many Japanese firms shift into the miscellaneous category because, like Toyota, they are controlled by groups without dominant members. Individual members of these groups hold very small equity stakes in sample companies, and even groups as a whole often have stakes of between 10 and 20 percent. In this respect, the Japanese model of ownership seems to be closer to that in other countries with good shareholder protection, like the US or the UK, than it is to the continental model. Specifically, most shares in Japanese firms are dispersed among small shareholders, there are no individual controlling shareholders, and even the groups have a relatively small share of the total votes. Of course, the groups may have control in excess of their voting rights because of lending and supply arrangements.

A comparison of countries with good and poor shareholder protection shows that widelyheld firms remain more common in the former: 34 percent versus only 16 percent in countries with poor shareholder protection $(t=-1.92)$. The latter countries have relatively more firms with ultimate owners in almost all categories: family, the State, and financial institutions, though the differences are not statistically significant. The bottom line is that the largest firms typically have owners, particularly in countries with poor shareholder protection.

What about the medium size firms, defined here as those with market valuations above, but near, $\$ 500$ million? Recall that we focus on these firms in part to address the criticism that firms in countries with good shareholder protection are larger, and hence have more dispersed ownership. Table $3 \mathrm{C}$ presents the results for these firms using the 20 percent chain definition of control. Among the medium firms, the world average incidence of dispersed ownership is 24 percent, compared to 36 percent for the large firms. So going down in size has the same effect as 
relaxing the strictness of the definition of control: it makes widely-held firms more scarce. Note, however, that in the US and the UK, though not in Japan, the medium firms remain mostly widely-held -- a testimony to the attractiveness of selling out in the US and the UK. For medium firms, the percentage of firms controlled by families rises to a world average of 45 percent, making it the dominant ownership pattern.

The comparison of countries with good and poor shareholder protection reinforces this picture. Only 13 percent (!) of the medium firms in poor protection countries are widely held, compared to 38 percent in good protection countries $(t=-2.86)$. Families control 39 percent of medium firms in the good shareholder protection countries, and 50 percent in the poor investor protection countries (the difference is not, however, statistically significant). State control is more common in bad protection countries: 20 percent versus 9 percent $(t=1.64$, significant at the 10 percent level). Using even the tough definition of control, we see that medium size firms generally have owners, especially in countries with poor shareholder protection.

Table $3 \mathrm{D}$ shows that, if we soften the definition of control by using the 10 percent control chain, only 11 percent of the medium size firms in the world are widely-held (though still 50 percent in the US and Ireland.) By contrast, 53 percent of firms are family-controlled, 16 percent are state controlled, and the remaining 20 percent are in other categories. Using this perfectly reasonable definition of control for medium firms makes dispersed ownership truly an exception.

Not surprisingly, it is even more of an exception in countries with poor shareholder protection, where only 6 percent of the firms are widely-held, compared to 17 percent in countries with good investor protection $(t=-1.83)$. In both groups, the predominant ownership pattern is family control. The conclusion from this evidence is inescapable: if we look at the 
largest firms in the world and a very tough definition of control, dispersed ownership is about as common as family ownership. But if we move from there to medium size firms, to more lenient

definition of control, and to countries with poor investor protection, widely-held firms become an exception. Berle and Means have created an accurate image of ownership of large American corporations, but it is far from a universal image.

\section{How are firms owned?}

In this subsection, we describe some of the mechanisms through which controlling shareholders exercise their power in the large firm sample. We address several related questions. First, how commonly are voting rights separated from cash flow rights through multiple classes of stock, cross-shareholdings, and pyramids? Second, how do families that control firms do so, and in particular is management separate from ownership in these firms? Third, do financial institutions play a bigger role in the control of firms than our earlier discussion has indicated? And finally, who, if anyone, monitors the controlling shareholders? By answering these questions, we hope to provide a more complete picture of ownership of very large firms, as well as suggest what might be some of the problems in the governance of such firms.

Table 4 begins by showing, for each country, the average fraction of book capital needed to control 20 percent of the votes, the incidence of cross-shareholdings by the sample firms, and the frequency of pyramids in firms with controlling owners at the 20 percent control level.

To begin, for these very large firms, the magnitude of deviations from one-share-one-vote through shares with differential voting rights tends to be small. In our sample, it takes on average about 18.6 percent of capital to control 20 percent of the votes, assuming that the only 
mechanism at the disposal of a controlling shareholder is shares with differential voting rights in the sample firm ${ }^{6}$. Companies obviously do not use anything like the opportunities for high and low voting shares allowed by national laws (La Porta et al. 1998). Indeed, even in countries with poor shareholder protection, it takes on average 17.7 percent of capital to buy 20 percent of the votes, compared to 19.7 percent for good shareholder protection countries $(t=-2.53)$. Some countries, particularly in Scandinavia, have much more significant deviations, but the average deviation from one-share-one-vote is small. The results suggest that muitiple classes of shares are not a central mechanism of separating ownership and control.

At the same time, fully 26 percent of firms that have ultimate owners are controlled through pyramids. That fraction is 18 percent in countries with good shareholder protection, and 31 percent in countries with poor protection. Relative to shares with differential voting rights, pyramidal ownership appears to be a more important mechanism used by controlling shareholders to separate their cash flow ownership in sample firms from their control rights. These results are consistent with Wolfenzohn's (1998) theory or pyramids, which suggests that they can be used by controlling shareholders to make existing shareholders pay the costs, but not share in all the benefits, of new ventures, particularly in countries with poor shareholder protection. Through pyramids, more so than through high voting rights shares, controlling shareholders possess power disproportionate to their cash flow rights. This evidence raises the concern of conflicting interests between the dominant and minority shareholders (Grossman and Hart 1986).

${ }^{6} \mathrm{We}$ do not, in this calculation, take account of the voting caps and other possible restrictions on voting in different countries. 
Finally, with the exception of a few countries, such as Sweden and Germany, crossshareholdings by sample firms are rare. In many countries they are illegal, but it still appears that they are used much less often than would be consistent with national laws.

Table 5 examines more specifically the firms that are controlled by families? ${ }^{7}$. The second column shows that in an average country, the ultimate family-owners control on average 25 percent of the value of the top 20 firms. Following up on the predominance of the Wallenbergs in Sweden, we also ask how many of the largest firms a controlling family controls, on average. Our sample average answer is 1.33 , though in countries like Israel and Sweden, an average ultimate family-owner controls 2.5 of the top 20 firms. Again, this is evidence of very significant control of productive resources by the largest shareholding families.

The next-to-last column of Table 5 speaks to the crucial issue concerning family control, namely the separation of ownership and management. We ask how often a member of the controlling family is the CEO, the Chairman. the Honorary Chairman, or the Vice-Chairman of the firm that the family controls. We do not catch all the family members by this procedure, since a CEO who is married into the family but does not have the same last name would not be recorded as a family member. For the universe as a whole, the answer is that (at least) 69 percent of the time families that control firms also participate in management. In countries with good shareholder protection, this fraction is 75 percent, whereas in countries with poor protection, it is 64 percent $(t=-2.33)$. This result shows that the standard problem of separation of ownership and management is not important for most of these firms, which is not to say that controlling

\footnotetext{
${ }^{7}$ On preliminary calculations, about a third of the family-controlled firms are run by their founders, and the rest by the descendants of founders or families that got to own them later.
} 
shareholders act in the interest of minorities.

Relative to the power of the families, significant ownership of equity by banks is rare, as Table 6 illustrates. The first column repeats the results from Table $3 \mathrm{~A}$ that only 5 percent of our large firms are controlled by financial institutions (mostly banks, but also insurance companies), and that this number is much higher in countries with poor than with good shareholder protection ( 7 versus 2 percent). But even in the former countries, bank ownership of equity is surprisingly small outside of Belgium (where it comes from French banks) and Germany. We also note that, where banks are controlling shareholders, they often control several of the largest firms, as is the case in Belgium, Portugal, and Sweden.

One reason for the scarcity of financial institutions as controlling shareholders in the largest firms may be that such institutions control smaller, but still influential, ownership stakes. We look for financial institutions outside the 20 percent control chains in two ways. First, we look for financials that have over 10 percent of votes, but are not part of the 10 percent control chain (independent financials). As the fourth column of Table 6 shows, only 6 percent of the firms in the sample have even such financials as shareholders. Second, we look for financial institutions that are themselves either controlling shareholders at the 10 percent level, or a link in a 10 percent control chain (not in itself evidence of having much control). Only 3 percent of the firms in the sample have such institutions. Thus even on looser definitions of significant ownership, financial institutions do not play a huge role in governance as significant shareholders outside a few countries, most notably Germany (Franks and Mayer 1994).

These results suggest to us that the German model of corporate governance, according to which banks own substantial equity stakes as well as provide loans to companies, is practiced 
mostly in Germany. This is not a huge endorsement of the German model, quite aside from the fact that the German financial institutions control each other and hence may be unaccountable.

More generally, these results leave us with a very different picture of separation of ownership and control than that suggested by Berle and Means. Widely held firms appear to be relatively uncommon, unless we look at specific countries, and focus on very restrictive measures of control and very large firms. In contrast, family control is very common. Families often have control rights over firms significantly in excess of their ownership rights, particularly through pyramids, and typically manage the firms they control. They are, indeed, the ultimate owners with control in the Berle and Means sense. Moreover, financial institutions do not appear to monitor these owners, surely not as shareholders. The question this raises is not one of agency conflicts between managers and controlling owners, but rather that of agency conflict between the controlling and the minority shareholders. Who keeps the controlling families from expropriating the minority shareholders, especially in countries with weak legal protection of minority shareholders, where family control is even more common? Who monitors the families?

One possibility is that there are other large shareholders, and that the large shareholders monitor each other, preventing each other from taking too much. The second possibility is that no one monitors the families. We can try to distinguish these possibilities by asking whether family (or other) controlling shareholders have other large shareholders in their firms.

Table 7 addresses this question. We say that the 20 percent controlling shareholder has a potential monitor if there is another shareholder that has a non-overlapping 10 percent chain of control. Thus, we suppose that monitoring the controlling shareholder does not require one to be as large. In the example of Electrabel from Section 2, the Frere family would be classified as a 
potential monitor to Suez. Using this definition, we find that large shareholders of all kinds, including family, are typically alone. Overall, the controlling shareholder does not have another large shareholder in the same firm in 75 percent of the cases, and this number is 71 percent for family controlling shareholders. These results are inconsistent with the hypothesis that controlling shareholders are usually monitored by other large shareholders.

In sum, this subsection has demonstrated that 1) controlling shareholders often have control rights in excess of their cash flow rights, 2) this is true of families, who are often the controlling shareholders, 3) controlling families participate in the management of the firms they own, 4) banks do not often exercise much control over firms as shareholders, and 5) other large shareholders are usually not there to monitor the controlling shareholders. Family control of firms appears to be common, significant, and typically unchallenged by other equity holders.

\section{Conclusion.}

Our results present a different picture of the ownership structure of a modern corporation than that suggested by Berle and Means and widely accepted in the finance literature. The Berle and Means widely-held corporation is only a common organizational form for large firms in the richest common law countries, one of which -- the United States -- Berle and Means actually had in mind. As we look outside the US, particularly at countries with poor shareholder protection, even the largest firms tend to have controlling shareholders. Sometimes that shareholder is the State; but more often it is a family, usually the founder of the firm or his descendants.

The controlling shareholders typically have control over firms considerably in excess of their cash flow rights. This is so in part because they often control large firms through pyramidal 
structures, and in part because they manage the firms they control. As a consequence, large firms have a problem of separation of ownership and control, but not the one described by Berle and Means. These firms are not run by professional managers without equity ownership who are unaccountable to shareholders; rather, they are run by controlling shareholders whose interests are unlikely to be the same as those of the minority shareholders. These controlling shareholders appear to be alone in having the dominant control of the large firms, and hence may have the power, and the interest, in expropriating the minorities. Restricting such expropriation is the real challenge to corporate governance in most countries.

Some of the consequences of the divergence of interests between the controlling and the minority shareholders are beginning to be understood. In countries with good shareholder protection, where expropriation of minority shareholders is limited by law, investors pay higher prices for their shares, and hence controlling shareholders are willing to reduce their stakes or even give up control. As a consequence, equity markets are both broader and more valuable in these countries (La Porta et al. 1997), and ownership is less concentrated. In contrast, poor shareholder protection countries have both more concentrated ownership of firms and narrower and smaller stock markets. In our sample, for example, market capitalization of the largest firms in countries like France and Italy is much smaller than it is in the UK, US or Japan. ${ }^{8}$

The result that ownership dispersion is a consequence of poor legal protection of minority shareholders casts doubt on the recently popular theory of Mark Roe (1994). Roe attributes ownership dispersion in the United States to US-specific policies that discourage ownership

${ }^{8}$ Consistent with this point of view, La Porta et al. (1998b) present evidence that firms in countries with good shareholder protection pay higher dividends than similar firms in countries with poor shareholder protection. 
concentration undertaken under political pressure from the professional corporate managers. The trouble is that the US shares relatively high ownership dispersion with other countries with good shareholder protection, particularly the other rich common law countries. Roe's US-specific theory of ownership dispersion is unlikely to be the whole story unless US-style anti-blockholder policies are common to all the countries with good shareholder protection.

Our analysis raises the obvious question of how the agency conflict between the controlling and the minority shareholders can be reduced. One obvious strategy is to improve the legal environment so as to make expropriation of minority shareholders more difficult. The European Corporate Governance Network (1997) stresses improved disclosure as the crucial element of such a strategy. This is surely an important element of reform, but it does not directly address the problem of poor shareholder protection. The Cadburry Committee (Charkham 1994) proposes mandatory changes in the structure of the boards of directors in European companies. We are not aware of any immediate relationship between board structures and the magnitude of expropriation of minority shareholders. Still other proposals suggest the mandatory requirement of one-share-one-vote in European countries; as our evidence indicates, this requirement will not make much difference as long as pyramids remain the principal strategy of separating ownership and control by the controlling shareholders. Indeed, legal reforms may need to be considerably more radical in nature, and give minority shareholders explicit rights to either prevent expropriation or seek remedy when it occurs, such as the opportunity to sue directors (perhaps through class action suits) for oppressive conduct (see also Berglof 1997).

An alternative view is that corporations seeking external capital will opt into legal regimes that are more protective of minorities without explicit legal reforms. The issuance of 
ADRs in New York by many Mexican and Israeli companies, with the attendant sharp increases in corporate disclosure though not minority shareholder rights, exemplifies this phenomenon. Unfortunately, a New York listing is prohibitively expensive for many companies. Alternatively, companies in countries with good shareholder protection, which have easier access to external funds, may acquire the less valuable companies in countries with poor investor protection, thereby bringing the assets of the latter into a more protective legal regime ${ }^{9}$. Lastly, companies may simply try to change their charters to attract portfolio investors.

Despite these ongoing market adjustments, it seems more likely to us that existing ownership structures are primarily an equilibrium response to the domestic legal environments that companies operate in. Competition for funds may accelerate the convergence of ownership structures to the Berle and Means model, but the convergence may still be slow. Unless, of course, there is rapid legal reform.

${ }^{9} \mathrm{~A}$ related phenomenon is for multinational firms to raise funds in countries with good investor protection to finance projects in countries with poor investor protection (Desai 1998). 
References

Barca, Fabrizio, (1995), "On Corporate Governance in Italy: Issues, Facts, and Agency," Manuscript, Bank of Italy, Rome.

Barclay, Michael, and Clifford Holderness, (1989), "Private Benefits from Control of Public Corporations," Journal of Financial Economics 25, 371-395.

Baumol, William, (1959), Business Behavior, Value and Growth. MacMillan, New York.

Bebchuk, Lucian, (1994), "Efficient and Inefficient Sales of Corporate Control," Quarterly Journal of Economics 109, 957-994.

Berglof, Eric, (1997), "Reforming Corporate Governance: Redirecting the European Agenda," Economic Policy 1997, 93-123.

Berglof, Eric, and Enrico Perotti, (1994), "The Governance Structure of the Japanese Financial Keiretsu," Journal of Financial Economics 36, 259-284.

Berle, Adolf, and Gardiner Means, (1932), The Modern Corporation and Private Property. MacMillan, New York.

Burkart, Mike, Denis Gromb, and Fausto Panunzi, (1997), "Large Shareholders, Monitoring, and Fiduciary Duty," Quarterly Journal of Economics 112, 693-728.

Burkart, Mike, Denis Gromb, and Fausto Panunzi, (1998), "Why Higher Takeover Premia Protect Minority Shareholders," Journal of Political Economy 106, 172-204.

Charkham, Jonathan, (1994), Keeping Good Company: A Study of Corporate Governance in Five Countries. Clarendon Press, Oxford.

Demsetz, Harold, (1983), "The Structure of Ownership and the Theory of the Firm," Journal of Law and Economics 26, 375-390. 
Demsetz, Harold, and Kenneth Lehn, (1985), "The Structure of Corporate Ownership: Causes and Consequences," Journal of Political Economy 93, 1155-1177.

Desai, Mihir, (1997), “A Multinational Perspective on Capital Structure Choice and Internal Capital Markets" Manuscript, Harvard University.

Edwards, Jeremy, and Klaus Fischer, (1994), Banks, Finance and Investment in West Germany Since 1970. Cambridge University Press, Cambridge.

Eisenberg, Melvin, (1976), The Structure of the Corporation: A Legal Analysis. Little, Brown and Co., Boston.

European Corporate Governance Network (1997), The Separation of Ownership and Control: $a$ Survey of 7 European Countries, Report Prepared for the European Commission.

Franks, Julian, and Colin Mayer, (1994), "The Ownership and Control of German Corporations," Manuscript, London Business School.

Galbraith, John Kenneth, (1967), The New Industrial State, Boston, MA: Houghton-Mifflin.

Gomes, Armando, (1996), "Dynamics of Stock Prices, Manager Ownership, and Private Benefits of Control," Manuscript, Harvard University.

Gorton, Gary, and Frank Schmid, (1996), "Universal Banking and the Performance of German Firms," Working Paper 5453, National Bureau of Economic Research, Cambridge, MA. Grossman, Sanford, and Oliver Hart, (1980), "Takeover Bids, the Free-rider Problem, and the Theory of the Corporation," Bell Journal of Economics 11, 42-64.

Grossman, Sanford, and Oliver Hart, (1986), "The Costs and Benefits of Ownership: a Theory of Vertical and Lateral Integration," Journal of Political Economy 94, 691-719.

Grossman, Sanford, and Oliver Hart, (1988), "One Share-One Vote and the Market for Corporate 
Control," Journal of Financial Economics 20, 175-202.

Harris, Milton and Artur Raviv, (1988), "Corporate Governance: Voting Rights and Majority Rules,"Journal of Financial Economics 20, 203-235.

Holderness, Clifford, and Dennis Sheehan, (1988), "The Role of Majority Shareholders in Publicly Held Corporations: An Exploratory Analysis," Journal of Financial Economics $20,317-346$.

Jensen, Michael, and William Meckling, (1976), "Theory of the Firm: Managerial Behavior, Agency Costs, and Ownership Structure," Journal of Financial Economics 3, 305-360. Kang, Jun-Koo, and Anil Shivdasani, (1995), "Firm Performance, Corporate Governance, and Top Executive Turnover in Japan," Journal of Financial Economics 38, 29-58.

La Porta, Rafael, Florencio Lopez-de-Silanes, Andrei Shleifer, and Robert W. Vishny, (1997), "Legal Determinants of External Finance," Journal of Finance 52, 1131-1150.

La Porta, Rafael, Florencio Lopez-de-Silanes, Andrei Shleifer, and Robert W. Vishny, (1998), "Law and Finance," Journal of Political Economy, forthcoming.

La Porta, Rafael, Florencio Lopez-de-Silanes, Andrei Shleifer, and Robert W. Vishny, (1998b), “Agency Problems and Dividend Policies around the World," Harvard University Mimeo. Marris, Robin, (1964), The Economic Theory of Managerial Capitalism. Free Press of Glencoe, Illinois.

Morck, Randall, Andrei Shleifer, and Robert Vishny, (1988), "Management Ownership and Market Valuation: An Empirical Analysis," Journal of Financial Economics 20, 293-315. Penrose, Edith, (1959), The Theory of the Growth of the Firm, Oxford, U.K.: Basil Blackwell. Prowse, Stephen, (1992), "The Structure of Corporate Ownership in Japan," Journal of Finance 
$47,1121-1140$.

Roe, Mark, (1994), Strong Managers Weak Owners: The Political Roots of American Corporate Finance. University Press, Princeton, NJ.

Shleifer, Andrei, and Robert Vishny, (1986), "Large Shareholders and Corporate Control," Journal of Political Economy 94, 461-488.

Shleifer, Andrei, and Robert Vishny, (1994), "Politicians and Firms," Quarterly Journal of Economics $109,955-1025$.

Shleifer, Andrei, and Robert W. Vishny, (1997), "A Survey of Corporate Governance," Journal of Finance 52, 737-783.

Stulz, Rene, (1988), "Managerial Control of Voting Rights: Financing Policies and the Market for Corporate Control," Journal of Financial Economics 20, 25-54.

Wells, Philippe, (1997), "Transfer Taxes and Survival of Family Firms: Evidence Across Countries," Manuscript, Harvard University.

Williamson, Oliver, (1964), The Economics of Discretionary Behavior: Managerial Objectives in a Theory of the Firm. Prentice Hall, Englewood Cliffs, NJ.

Wolfenzohn, Daniel (1998), “A Theory or Pyramidal Ownership,” Harvard University Mimeo. Yafeh, Yishay, and Oved Yosha, (1996), "Large Shareholders and Banks: Who Monitors and How?" Manuscript, Hebrew University, Jerusalem, Israel. 


\section{Table 1: Some Facts On Ownership Around The World}

1. Companies have owners. The Berle-Means widely held corporation is far from universal.

2. The widely held corporation is more common in countries with good shareholder protection.

3. Many of the largest firms are controlled by families.

4. Family control is more common in countries with poor shareholder protection.

5. State control of traded firms is common, particularly in countries with poor shareholder protection.

6. Control by widely held banks or widely held corporations is uncommon. Even outside the control chain, significant bank ownership is infrequent.

7. Among the largest firms, deviations from one share one vote are small, but pyramids are more common. Cross-ownership is rare.

8. Pyramids and deviations from one share one vote are more common in countries with poor shareholder protection.

9. In family controlled firms, there is little separation between ownership and management.

10. Firms with controlling shareholders rarely have other large shareholders. 
Table 2: Definition of the Variables

\begin{tabular}{|c|c|}
\hline Variable & Description \\
\hline $\begin{array}{l}\text { Anti-director } \\
\text { Index }\end{array}$ & $\begin{array}{l}\text { An index aggregating shareholder rights which we labeled as "anti-director rights". The index is } \\
\text { formed by adding } 1 \text { when: (1) the country allows shareholders to mail their proxy vote to the firm; } \\
\text { (2) shareholders are not required to deposit their shares prior to a General Shareholder's Meeting; } \\
\text { (3) cumulative voting or proportional representation of minorities in the board of directors is } \\
\text { allowed; (4) an oppressed minorities mechanism is in place; (5) the minimum percentage of share } \\
\text { capital that entitles a shareholder to call an Extraordinary Shareholders' Meeting is less than or } \\
\text { equal to } 10 \% \text {; or (6) shareholders have preemptive rights that can only be waved by a shareholders' } \\
\text { vote. The index ranges from } 0 \text { to } 6 \text {. Source: La Porta et al. (1998). }\end{array}$ \\
\hline Widely Held & $\begin{array}{l}\text { Equals } 1 \text { if there is no controlling shareholder. To measure control we combine a shareholder's } \\
\text { direct (i.e, through shares registered in her name) and indirect (i.e, through shares held by entities } \\
\text { that, in tum, she controls) voting rights in the firm. A shareholder has an } x \% \text { indirect control over } \\
\text { firm } \mathrm{A} \text { if: (1) it controls directly firm B which, in turn, directly controls } \mathrm{x} \% \text { of the votes in firm A; } \\
\text { or (2) it controls directly firm } \mathrm{C} \text { which in turn controls firm B (or a sequence of firms leading to } \\
\text { firm B each of which has control over the next one, i.e. they form a control chain) which, in turn, } \\
\text { directly controls } \mathrm{x} \% \text { of the votes in firm A. A group of n companies form a chain of control if } \\
\text { each firm } 1 \text { through } \mathrm{n}-1 \text { controls the subsequent firm. Therefore, a firm in our sample has a } \\
\text { controlling shareholder if the sum of her direct and indirect voting rights exceeds an arbitrary cutoff } \\
\text { value, which, alternatively, is } 20 \% \text { or } 10 \% \text {. When two or more shareholders meet our criteria for } \\
\text { control, we assign control to the shareholder with the largest (direct plus indirect) voting stake. }\end{array}$ \\
\hline Family & Equals 1 if a person or a family is the controlling shareholder, and 0 otherwise. \\
\hline State & Equals 1 if the (domestic or foreign) state is the controlling shareholder, and 0 otherwise. \\
\hline $\begin{array}{l}\text { Widely Held } \\
\text { Financial }\end{array}$ & Equals 1 if a widely held financial company is the controlling shareholder and 0 otherwise. \\
\hline $\begin{array}{l}\text { Widely Held } \\
\text { Corporation }\end{array}$ & Equals 1 if a widely held non-financial company is the controlling shareholder, and 0 otherwise. \\
\hline Miscellaneous & $\begin{array}{l}\text { Equals } 1 \text { if Widely Held, Family, State, Widely Held Financial and Widely Held Corporation are } \\
\text { all equal to } 0 \text {, and } 0 \text { otherwise. It includes control by pension funds, mutual funds, voting trusts, } \\
\text { management trusts, groups, subsidiaries (firms that, in turn, are at least } 50 \% \text { owned by the firm in } \\
\text { the sample), non-profit organizations, and employees. }\end{array}$ \\
\hline $\mathrm{Cap}=20 \% \mathrm{~V}$ & $\begin{array}{l}\text { Minimum percent of the book value of common equity required to control twenty percent of the } \\
\text { votes. Source: Moodys International. }\end{array}$ \\
\hline Cross-Shhs & $\begin{array}{l}\text { Equals } 1 \text { if the firm owns shares in its controlling shareholder or in a firm that belongs to her chain } \\
\text { of control, and } 0 \text { otherwise. }\end{array}$ \\
\hline Pyramid & $\begin{array}{l}\text { Equals } 1 \text { if the controlling shareholder exercises control through at least one publicly-traded } \\
\text { company, and } 0 \text { otherwise. }\end{array}$ \\
\hline $\begin{array}{l}\text { Share Mkt } \\
\text { Cap }\end{array}$ & $\begin{array}{l}\text { Ratio of the sum of the market value of common equity of all firms controlled by the relevant type } \\
\text { of owner (i.e., Family, State, or Widely Held Financial) to the total market value of common equity } \\
\text { of the largest twenty firms in a given country. }\end{array}$ \\
\hline N Firms & $\begin{array}{l}\text { Average number of firms controlled by the relevant type of owner (i.e., Family or Widely Held } \\
\text { Financial). }\end{array}$ \\
\hline
\end{tabular}




\begin{tabular}{l|l}
\hline Variable & \multicolumn{1}{c}{ Description } \\
\hline Management & $\begin{array}{l}\text { Equals 1 if the controlling family is also the CEO, Honorary Chairman, Chairman or Vice- } \\
\text { Chairman of the Board, and 0 if they don't hold any of the mentioned positions. }\end{array}$ \\
\hline $\begin{array}{l}\text { Independent } \\
\text { Financials }\end{array}$ & $\begin{array}{l}\text { Equals I when a (widely-held) financial institution controls at least 10\% of the votes and its control } \\
\text { chain is separate from that of the controlling owner, and 0 otherwise. More precisely, the variable } \\
\text { takes value of 1 when the following three conditions are met: (1) it controls at least } 10 \% \text { of the } \\
\text { votes of the firm; (2) it is not the controlling owner; and (3) its control chain does not overlap with } \\
\text { that of the controlling owner. }\end{array}$ \\
\hline $\begin{array}{l}\text { Associated } \\
\text { Financials }\end{array}$ & $\begin{array}{l}\text { Equals 1 when a (widely-held) financial institution controls at least 10\% of the votes and its control } \\
\text { chain overlaps with that of the controlling owner, and 0 otherwise. More precisely, equals 1 when } \\
\text { a financial institution meets the following three conditions: (1) it controls at least 10\% of the votes } \\
\text { of the firm; (2) it is not the controlling owner; and (3) its control chain overlaps with that of the } \\
\text { controlling owner. }\end{array}$ \\
\hline Alone & $\begin{array}{l}\text { Equals 1 if the firm has a 20\% controlling owner and no other shareholder has control of at least } \\
10 \% \text { of the votes through a control chain that does not overlap with that of the controlling } \\
\text { shareholder. Equals 0 if the firm has a shareholder other than the controlling one with at } \\
\text { least 10\% of the votes through a control chain that does not overlap with that of the the } \\
\text { controlling shareholder. The variable is otherwise set to missing. }\end{array}$ \\
\hline
\end{tabular}




\section{Table 3A: Control (20\%) of Large Publicly Traded Firms Around the World}

This table classifies countries according to their ranking in antidirector rights. We form two groups of countries: (1) High anti-directors; and (2) low anti-directors depending on whether the country's anti-director score is above the median or not. Panel A presents means for each variable using $20 \%$ as the criteria for control for a sample of the largest twenty firms (by stock market capitalization of equity at the end of 1995) in twenty-seven countries. Definitions for each of the variables can be found in Table 2. Panel B reports tests of means for countries above and below the median antidirector rights.

\begin{tabular}{|c|c|c|c|c|c|c|}
\hline Country & $\begin{array}{l}\text { Widely } \\
\text { Held }\end{array}$ & Family & State & $\begin{array}{l}\text { Widely Held } \\
\text { Financial }\end{array}$ & $\begin{array}{l}\text { Widely Held } \\
\text { Corporation }\end{array}$ & Miscellaneous \\
\hline & \multicolumn{6}{|c|}{ Panel A: Means } \\
\hline Argentina & 0.00 & 0.65 & 0.15 & 0.05 & 0.15 & 0.00 \\
\hline Australia & 0.65 & 0.05 & 0.05 & 0.00 & 0.25 & 0.00 \\
\hline Canada & 0.60 & 0.25 & 0.00 & 0.00 & 0.15 & 0.00 \\
\hline Hong Kong & 0.10 & 0.70 & 0.05 & 0.05 & 0.00 & 0.10 \\
\hline Ireland & 0.65 & 0.10 & 0.00 & 0.00 & 0.10 & 0.15 \\
\hline Japan & 0.90 & 0.05 & 0.05 & 0.00 & 0.00 & 0.00 \\
\hline New Zealand & 0.30 & 0.25 & 0.25 & 0.00 & 0.20 & 0.00 \\
\hline Norway & 0.25 & 0.25 & 0.35 & 0.05 & 0.00 & 0.10 \\
\hline Singapore & 0.15 & 0.30 & 0.45 & 0.05 & 0.05 & 0.00 \\
\hline Spain & 0.35 & 0.15 & 0.30 & 0.10 & 0.10 & 0.00 \\
\hline UK & 1.00 & 0.00 & 0.00 & 0.00 & 0.00 & 0.00 \\
\hline US & 0.80 & 0.20 & 0.00 & 0.00 & 0.00 & 0.00 \\
\hline High Anti-director Avg & 0.4792 & 0.2458 & 0.1375 & 0.0250 & 0.0833 & 0.0292 \\
\hline Austria & 0.05 & 0.15 & 0.70 & 0.00 & 0.00 & 0.10 \\
\hline Belgium & 0.05 & 0.50 & 0.05 & 0.30 & 0.00 & 0.10 \\
\hline Denmark & 0.40 & 0.35 & 0.15 & 0.00 & 0.00 & 0.10 \\
\hline Finland & 0.35 & 0.10 & 0.35 & 0.05 & 0.05 & 0.10 \\
\hline France & 0.60 & 0.20 & 0.15 & 0.05 & 0.00 & 0.00 \\
\hline Germany & 0.50 & 0.10 & 0.25 & 0.15 & 0.00 & 0.00 \\
\hline Greece & 0.10 & 0.50 & 0.30 & 0.10 & 0.00 & 0.00 \\
\hline Israel & 0.05 & 0.50 & 0.40 & 0.00 & 0.05 & 0.00 \\
\hline Italy & 0.20 & 0.15 & 0.40 & 0.05 & 0.10 & 0.10 \\
\hline South Korea & 0.55 & 0.20 & 0.15 & 0.00 & 0.05 & 0.05 \\
\hline Mexico & 0.00 & 1.00 & 0.00 & 0.00 & 0.00 & 0.00 \\
\hline Netherlands & 0.30 & 0.20 & 0.05 & 0.00 & 0.10 & 0.35 \\
\hline Portugal & 0.10 & 0.45 & 0.25 & 0.15 & 0.00 & 0.05 \\
\hline Sweden & 0.25 & 0.45 & 0.10 & 0.15 & 0.00 & 0.05 \\
\hline Switzerland & 0.60 & 0.30 & 0.00 & 0.05 & 0.00 & 0.05 \\
\hline Low Anti-director Avg & 0.2733 & 0.3433 & 0.2200 & 0.0700 & 0.0233 & 0.0700 \\
\hline Sample Average & 0.3648 & 0.3000 & 0.1833 & 0.0500 & 0.0500 & 0.0519 \\
\hline
\end{tabular}

Panel B: Test of Means (t-statistic)

\begin{tabular}{llllllll} 
Low vs High Anti-director & -1.95 & 1.09 & 1.20 & 1.70 & -2.38 & 1.40 \\
\hline
\end{tabular}




\section{Table 3B: Control (10\%) of Large Publicly Traded Firms Around the World}

This tabie classifies countries according to their ranking in antidirector rights. We form two groups of countries: (1) High anti-directors; and (2) low anti-directors depending on whether the country's anti-director score is above the median or not. Panel A presents means for each variable using $10 \%$ as the criteria for control for a sample of the largest twenty firms (by stock market capitalization of equity at the end of 1995) in twenty-seven countries. Definitions for each of the variables can be found in Table 2. Panel B reports tests of means for countries above and below the median antidirector rights.

\begin{tabular}{|c|c|c|c|c|c|c|}
\hline Country & $\begin{array}{l}\text { Widely } \\
\text { Held }\end{array}$ & Family & State & $\begin{array}{l}\text { Widely Held } \\
\text { Financial }\end{array}$ & $\begin{array}{l}\text { Widely Held } \\
\text { Corporation }\end{array}$ & Miscellaneous \\
\hline & \multicolumn{6}{|c|}{ Panel A: Means } \\
\hline Argentina & 0.00 & 0.65 & 0.20 & 0.10 & 0.05 & 0.00 \\
\hline Australia & 0.55 & 0.10 & 0.05 & 0.05 & 0.25 & 0.00 \\
\hline Canada & 0.50 & 0.30 & 0.00 & 0.00 & 0.15 & 0.05 \\
\hline Hong Kong & 0.10 & 0.70 & 0.05 & 0.05 & 0.00 & 0.10 \\
\hline Ireland & 0.45 & 0.15 & 0.00 & 0.05 & 0.05 & 0.30 \\
\hline Japan & 0.50 & 0.10 & 0.05 & 0.00 & 0.00 & 0.35 \\
\hline New Zealand & 0.05 & 0.45 & 0.25 & 0.05 & 0.20 & 0.00 \\
\hline Norway & 0.05 & 0.25 & 0.40 & 0.10 & 0.00 & 0.20 \\
\hline Singapore & 0.05 & 0.45 & 0.45 & 0.00 & 0.00 & 0.05 \\
\hline Spain & 0.15 & 0.25 & 0.45 & 0.15 & 0.00 & 0.00 \\
\hline UK & 0.90 & 0.05 & 0.00 & 0.05 & 0.00 & 0.00 \\
\hline US & 0.80 & 0.20 & 0.00 & 0.00 & 0.00 & 0.00 \\
\hline High Anti-direct. Avg & 0.3417 & 0.3042 & 0.1583 & 0.0500 & 0.0583 & 0.0875 \\
\hline Austria & 0.05 & 0.15 & 0.70 & 0.00 & 0.00 & 0.10 \\
\hline Belgium & 0.00 & 0.50 & 0.05 & 0.35 & 0.00 & 0.10 \\
\hline Denmark & 0.10 & 0.35 & 0.20 & 0.05 & 0.00 & 0.30 \\
\hline Finland & 0.15 & 0.10 & 0.35 & 0.25 & 0.00 & 0.15 \\
\hline France & 0.30 & 0.20 & 0.20 & 0.20 & 0.10 & 0.00 \\
\hline Germany & 0.35 & 0.10 & 0.30 & 0.25 & 0.00 & 0.00 \\
\hline Greece & 0.05 & 0.65 & 0.30 & 0.00 & 0.00 & 0.00 \\
\hline Israel & 0.05 & 0.50 & 0.40 & 0.00 & 0.05 & 0.00 \\
\hline Italy & 0.15 & 0.20 & 0.50 & 0.00 & 0.00 & 0.15 \\
\hline South Korea & 0.40 & 0.35 & 0.15 & 0.00 & 0.05 & 0.05 \\
\hline Mexico & 0.00 & 1.00 & 0.00 & 0.00 & 0.00 & 0.00 \\
\hline Netherlands & 0.30 & 0.20 & 0.05 & 0.00 & 0.10 & 0.35 \\
\hline Portugal & 0.00 & 0.50 & 0.25 & 0.20 & 0.00 & 0.05 \\
\hline Sweden & 0.00 & 0.55 & 0.10 & 0.30 & 0.00 & 0.05 \\
\hline Switzerland & 0.50 & 0.40 & 0.00 & 0.05 & 0.00 & 0.05 \\
\hline Low Anti-direct. Avg & 0.1600 & 0.3833 & 0.2367 & 0.1100 & 0.0200 & 0.0900 \\
\hline \multirow[t]{2}{*}{ Sample Average } & 0.2407 & 0.3481 & 0.2019 & 0.0833 & 0.0370 & 0.0889 \\
\hline & \multicolumn{6}{|c|}{ Panel B: Test of Means (t-statistic) } \\
\hline Low vs High Anti-dir. & -1.92 & 0.88 & 1.05 & 1.50 & -1.50 & 0.06 \\
\hline
\end{tabular}


Table 3C: Control (20\%) of Medium-Sized Publicly Traded Firms Around the World

This table classifies countries according to their ranking in antidirector rights. We form two groups of countries: (1) High anti-directors; and (2) low anti-directors depending on whether the country's anti-director score is above the median or not. Panel A presents means for each variable using $20 \%$ as the criteria for control for a sample of ten firms with stock market capitalization of common equity at the end of December of 1995 of at least $\$ 500$ million or higher in twenty-seven countries. Definitions for each of the variables can be found in Table 2. Panel B reports tests of means for countries above and below the median antidirector rights.

\begin{tabular}{|c|c|c|c|c|c|c|}
\hline Country & $\begin{array}{l}\text { Widely } \\
\text { Held }\end{array}$ & Family & State & $\begin{array}{l}\text { Widely Held } \\
\text { Financial }\end{array}$ & $\begin{array}{l}\text { Widely Held } \\
\text { Corporation }\end{array}$ & Miscellaneous \\
\hline & \multicolumn{6}{|c|}{ Panel A: Means } \\
\hline Argentina & 0.00 & 0.80 & 0.20 & 0.00 & 0.00 & 0.00 \\
\hline Australia & 0.30 & 0.50 & 0.00 & 0.00 & 0.20 & 0.00 \\
\hline Canada & 0.60 & 0.30 & 0.10 & 0.00 & 0.00 & 0.00 \\
\hline Hong Kong & 0.00 & 0.90 & 0.00 & 0.00 & 0.00 & 0.10 \\
\hline Ireland & 0.63 & 0.13 & 0.00 & 0.00 & 0.13 & 0.13 \\
\hline Japan & 0.30 & 0.10 & 0.00 & 0.00 & 0.00 & 0.60 \\
\hline New Zealand & 0.57 & 0.29 & 0.14 & 0.00 & 0.00 & 0.00 \\
\hline Norway & 0.20 & 0.40 & 0.20 & 0.10 & 0.00 & 0.10 \\
\hline Singapore & 0.40 & 0.40 & 0.20 & 0.00 & 0.00 & 0.00 \\
\hline Spain & 0.00 & 0.30 & 0.20 & 0.40 & 0.10 & 0.00 \\
\hline UK & 0.60 & 0.40 & 0.00 & 0.00 & 0.00 & 0.00 \\
\hline US & 0.90 & 0.10 & 0.00 & 0.00 & 0.00 & 0.00 \\
\hline High Anti-direct. Avg & 0.3750 & 0.3850 & 0.0867 & 0.0417 & 0.0358 & 0.0775 \\
\hline Austria & 0.00 & 0.17 & 0.83 & 0.00 & 0.00 & 0.00 \\
\hline Belgium & 0.20 & 0.40 & 0.30 & 0.10 & 0.00 & 0.00 \\
\hline Denmark & 0.30 & 0.40 & 0.20 & 0.00 & 0.00 & 0.10 \\
\hline Finland & 0.20 & 0.20 & 0.20 & 0.10 & 0.10 & 0.20 \\
\hline France & 0.00 & 0.50 & 0.20 & 0.20 & 0.00 & 0.10 \\
\hline Germany & 0.10 & 0.40 & 0.20 & 0.20 & 0.10 & 0.00 \\
\hline Greece & 0.00 & 1.00 & 0.00 & 0.00 & 0.00 & 0.00 \\
\hline Israel & 0.10 & 0.60 & 0.30 & 0.00 & 0.00 & 0.00 \\
\hline Italy & 0.00 & 0.60 & 0.00 & 0.00 & 0.10 & 0.30 \\
\hline South Korea & 0.30 & 0.50 & 0.00 & 0.00 & 0.20 & 0.00 \\
\hline Mexico & 0.00 & 1.00 & 0.00 & 0.00 & 0.00 & 0.00 \\
\hline Netherlands & 0.10 & 0.20 & 0.10 & 0.00 & 0.10 & 0.50 \\
\hline Portugal & 0.00 & 0.50 & 0.50 & 0.00 & 0.00 & 0.00 \\
\hline Sweden & 0.10 & 0.60 & 0.20 & 0.00 & 0.00 & 0.10 \\
\hline Switzerland & 0.50 & 0.50 & 0.00 & 0.00 & 0.00 & 0.00 \\
\hline Low Anti-direct. Avg & 0.1267 & 0.5047 & 0.2020 & 0.0400 & 0.0400 & 0.0867 \\
\hline Sample Average & 0.2370 & 0.4515 & 0.1507 & 0.0407 & 0.0381 & 0.0826 \\
\hline
\end{tabular}

Panel B: Test of Means (t-statistic)

Low vs High Anti-dir.

$-2.86$

1.24

1.64

$-0.45$

0.18

0.16 
Table 3D: Control (10\%) of Medium-Sized Publicly Traded Firms Around the World

This table classifies countries according to their ranking in antidirector rights. We form two groups of countries: (1) High anti-directors; and (2) low anti-directors depending on whether the country's anti-director score is above the median or not. Panel A presents means for each variable using $10 \%$ as the criteria for control for a sample of ten firms with stock market capitalization of common equity at the end of December of 1995 of at least $\$ 500$ million in twenty-seven countries. Definitions for each of the variables can be found in Table 2. Panel B reports tests of means for countries above and below the median antidirector rights.

\begin{tabular}{|c|c|c|c|c|c|c|}
\hline Country & $\begin{array}{l}\text { Widely } \\
\text { Held }\end{array}$ & Family & State & $\begin{array}{c}\text { Widely Held } \\
\text { Financial }\end{array}$ & $\begin{array}{l}\text { Widely Held } \\
\text { Corporation }\end{array}$ & Miscellaneous \\
\hline & \multicolumn{6}{|c|}{ Panel A: Means } \\
\hline Argentina & 0.00 & 0.80 & 0.20 & 0.00 & 0.00 & 0.00 \\
\hline Australia & 0.10 & 0.50 & 0.00 & 0.10 & 0.20 & 0.10 \\
\hline Canada & 0.40 & 0.50 & 0.10 & 0.00 & 0.00 & 0.00 \\
\hline Hong Kong & 0.00 & 0.90 & 0.00 & 0.00 & 0.00 & 0.10 \\
\hline Ireland & 0.50 & 0.25 & 0.00 & 0.00 & 0.00 & 0.25 \\
\hline Japan & 0.20 & 0.10 & 0.00 & 0.00 & 0.00 & 0.70 \\
\hline New Zealand & 0.00 & 0.86 & 0.14 & 0.00 & 0.00 & 0.00 \\
\hline Norway & 0.10 & 0.40 & 0.20 & 0.10 & 0.00 & 0.20 \\
\hline Singapore & 0.10 & 0.60 & 0.30 & 0.00 & 0.00 & 0.00 \\
\hline Spain & 0.00 & 0.30 & 0.30 & 0.40 & 0.00 & 0.00 \\
\hline UK & 0.10 & 0.60 & 0.00 & 0.10 & 0.00 & 0.20 \\
\hline US & 0.50 & 0.30 & 0.00 & 0.00 & 0.00 & 0.20 \\
\hline High Anti-direct. Avg & 0.1667 & 0.5092 & 0.1033 & 0.0583 & 0.0167 & 0.1458 \\
\hline Austria & 0.00 & 0.17 & 0.83 & 0.00 & 0.00 & 0.00 \\
\hline Belgium & 0.10 & 0.40 & 0.30 & 0.20 & 0.00 & 0.00 \\
\hline Denmark & 0.00 & 0.40 & 0.20 & 0.00 & 0.00 & 0.40 \\
\hline Finland & 0.00 & 0.20 & 0.20 & 0.20 & 0.10 & 0.30 \\
\hline France & 0.00 & 0.50 & 0.20 & 0.20 & 0.00 & 0.10 \\
\hline Germany & 0.10 & 0.40 & 0.20 & 0.30 & 0.00 & 0.00 \\
\hline Greece & 0.00 & 1.00 & 0.00 & 0.00 & 0.00 & 0.00 \\
\hline Israel & 0.10 & 0.60 & 0.30 & 0.00 & 0.00 & 0.00 \\
\hline Italy & 0.00 & 0.80 & 0.10 & 0.00 & 0.00 & 0.10 \\
\hline South Korea & 0.00 & 0.80 & 0.00 & 0.00 & 0.20 & 0.00 \\
\hline Mexico & 0.00 & 1.00 & 0.00 & 0.00 & 0.00 & 0.00 \\
\hline Netherlands & 0.10 & 0.20 & 0.10 & 0.00 & 0.10 & 0.50 \\
\hline Portugal & 0.00 & 0.50 & 0.50 & 0.00 & 0.00 & 0.00 \\
\hline Sweden & 0.10 & 0.60 & 0.20 & 0.10 & 0.00 & 0.00 \\
\hline Switzerland & 0.40 & 0.50 & 0.00 & 0.00 & 0.00 & 0.10 \\
\hline Low Anti-direct. Avg & 0.0600 & 0.5380 & 0.2087 & 0.0667 & 0.0267 & 0.1000 \\
\hline Sample Average & 0.1074 & 0.5252 & 0.1619 & 0.0630 & 0.0222 & 0.1204 \\
\hline
\end{tabular}

Panel B: Test of Means (t-statistic)

Low vs High Anti-dir.

$-1.83$

0.28

1.47

0.20

0.44

$-0.65$ 
Table 4: One-Share-One-Vote, Cross-Shareholdings, and Pyramids

This table classifies countries according to their ranking in antidirector rights. We form two groups of countries: (1) High anti-directors; and (2) low anti-directors depending on whether the country's anti-director score is above the median or not. Panel A presents means for each variable using $20 \%$ as the criteria for control for a sample of the largest twenty firms (by stock market capitalization of equity at the end of 1995) in twenty-seven countries. Definitions for each of the variables can be found in Table 2. Panel B reports tests of means for countries above and below the median antidirector rights.

\begin{tabular}{|c|c|c|c|}
\hline Country & $\mathrm{Cap}=20 \% \mathrm{~V}$ & $\begin{array}{l}\text { Pyramid \& Not Widely } \\
\text { Held }\end{array}$ & Cross-Shhs \\
\hline \multicolumn{4}{|c|}{ Panel A: Means } \\
\hline Argentina & 19.6013 & 0.05 & 0.00 \\
\hline Australia & 20.0000 & 0.14 & 0.10 \\
\hline Canada & 19.3618 & 0.13 & 0.00 \\
\hline Hong Kong & 19.5107 & 0.39 & 0.05 \\
\hline Ireland & 20.0000 & 0.00 & 0.00 \\
\hline Japan & 20.0000 & 0.00 & 0.00 \\
\hline New Zealand & 20.0000 & 0.36 & 0.00 \\
\hline Norway & 18.1548 & 0.13 & 0.00 \\
\hline Singapore & 20.0000 & 0.41 & 0.10 \\
\hline Spain & 20.0000 & 0.38 & 0.00 \\
\hline UK & 20.0000 & . & 0.00 \\
\hline US & 19.1927 & 0.00 & 0.00 \\
\hline High Anti-director Avg & 19.6518 & 0.1808 & 0.0208 \\
\hline Austria & 19.8933 & 0.47 & 0.15 \\
\hline Belgium & 20.0000 & 0.79 & 0.05 \\
\hline Denmark & 14.8661 & 0.08 & 0.00 \\
\hline Finland & 15.7533 & 0.00 & 0.00 \\
\hline France & 19.9957 & 0.38 & 0.00 \\
\hline Germany & 18.6137 & 0.40 & 0.20 \\
\hline Greece & 20.0000 & 0.11 & 0.00 \\
\hline Israel & 20.0000 & 0.53 & 0.00 \\
\hline Italy & 18.0399 & 0.25 & 0.00 \\
\hline South Korea & 20.0000 & 0.33 & 0.05 \\
\hline Mexico & 16.4490 & 0.25 & 0.00 \\
\hline Netherlands & 15.0000 & 0.14 & 0.00 \\
\hline Portugal & 20.0000 & 0.44 & 0.05 \\
\hline Sweden & 12.6283 & 0.53 & 0.10 \\
\hline Switzerland & 14.1783 & 0.00 & 0.00 \\
\hline Low Anti-director Avg & 17.6945 & 0.3137 & 0.0400 \\
\hline Sample Average & 18.5644 & 0.2575 & 0.0315 \\
\hline
\end{tabular}

Panel B: Test of Means (t-statistic) 
Table 5: Family Control in a Sample of Large Publicly Traded Firms Around the World

This table classifies countries according to their ranking in antidirector rights. We form two groups of countries: (1) High anti-directors; and (2) low anti-directors depending on whether the country's anti-director score is above the median or not. Panel A presents means for each variable using $20 \%$ as the criteria for control for a sample of the largest twenty firms (by stock market capitalization of equity at the end of 1995) in twenty-seven countries. Definitions for each of the variables can be found in Table 2 . Panel B reports tests of means for countries above and below the median antidirector rights.

\begin{tabular}{|c|c|c|c|c|c|}
\hline Country & Family & Share Mkt Cap & N Firms & Management & Pyramids \\
\hline & \multicolumn{5}{|c|}{ Panel A: Means } \\
\hline Argentina & 0.65 & 0.5258 & 1.18 & 0.62 & 0.00 \\
\hline Australia & 0.05 & 0.1218 & 1.00 & 1.00 & 0.00 \\
\hline Canada & 0.25 & 0.2770 & 1.25 & 1.00 & 0.20 \\
\hline Hong Kong & 0.70 & 0.6342 & 1.56 & 0.86 & 0.50 \\
\hline Ireland & 0.10 & 0.0417 & 2.00 & 1.00 & 0.00 \\
\hline Japan & 0.05 & 0.0287 & 1.00 & 1.00 & 0.00 \\
\hline New Zealand & 0.25 & 0.1511 & 1.00 & 0.60 & 0.40 \\
\hline Norway & 0.25 & 0.1327 & 1.00 & 0.80 & 0.00 \\
\hline Singapore & 0.30 & 0.1514 & 1.20 & 0.67 & 0.67 \\
\hline Spain & 0.15 & 0.1697 & 1.50 & 0.67 & 0.33 \\
\hline UK & 0.00 & 0.0000 & . & . & . \\
\hline US & 0.20 & 0.1827 & 1.00 & 0.75 & 0.00 \\
\hline High Anti-dir. Avg & 0.2458 & 0.2014 & 1.2441 & 0.7475 & 0.1909 \\
\hline Austria & 0.15 & 0.0620 & 1.50 & 0.33 & 0.67 \\
\hline Belgium & 0.50 & 0.4124 & 1.67 & 0.50 & 0.80 \\
\hline Denmark & 0.35 & 0.3167 & 1.17 & 0.57 & 0.14 \\
\hline Finland & 0.10 & 0.0613 & 1.00 & 0.50 & 0.00 \\
\hline France & 0.20 & 0.2569 & 1.00 & 0.75 & 0.25 \\
\hline Germany & 0.10 & 0.0751 & 1.00 & 0.50 & 0.00 \\
\hline Greece & 0.50 & 0.4746 & 1.00 & 0.60 & 0.00 \\
\hline Israel & 0.50 & 0.3099 & 2.50 & 0.60 & 0.60 \\
\hline Italy & 0.15 & 0.1424 & 1.50 & 1.00 & 0.33 \\
\hline South Korea & 0.20 & 0.2160 & 1.33 & 0.75 & 0.50 \\
\hline Mexico & 1.00 & 1.0000 & 1.05 & 0.95 & 0.25 \\
\hline Netherlands & 0.20 & 0.0610 & 1.00 & 0.50 & 0.25 \\
\hline Portugal & 0.45 & 0.3798 & 1.80 & 0.44 & 0.44 \\
\hline Sweden & 0.45 & 0.3545 & 2.50 & 0.56 & 0.78 \\
\hline Switzerland & 0.30 & 0.2874 & 1.00 & 1.00 & 0.00 \\
\hline Low Anti-dir. Avg & 0.3433 & 0.2940 & 1.4010 & 0.6367 & 0.3343 \\
\hline \multirow[t]{2}{*}{ Sample Average } & 0.3000 & 0.2528 & 1.3347 & 0.6859 & 0.2736 \\
\hline & \multicolumn{5}{|c|}{ Panel B: Test of Means (t-statistic) } \\
\hline Low vs High Anti-dir. & 1.09 & 1.06 & 0.94 & -2.33 & 1.34 \\
\hline
\end{tabular}


Table 6: Control by Financial Institutions in a Sample of Large Firms in Twenty-Seven Countries This table classifies countries according to their ranking in antidirector rights. We form two groups of countries: (1) High antidirectors; and (2) low anti-directors depending on whether the country's anti-director score is above the median or not. Panel A presents means for each variable using $20 \%$ as the criteria for control for a sample of the largest twenty firms (by stock market capitalization of equity at the end of 1995) in twenty-seven countries. Definitions for each of the variables can be found in Table 2. Panel B reports tests of means for countries above and below the median antidirector rights.

\begin{tabular}{|c|c|c|c|c|c|c|}
\hline \multirow[t]{2}{*}{ Country } & \multirow{2}{*}{$\begin{array}{c}\text { Widely Held } \\
\text { Financial }\end{array}$} & \multirow{2}{*}{$\begin{array}{c}\text { Share Mkt } \\
\text { Capital }\end{array}$} & \multirow[t]{2}{*}{ N Firms } & \multicolumn{2}{|c|}{ Financ. Inst. not Dominant } & \multirow[t]{2}{*}{ Pyramid } \\
\hline & & & & Independent & Associated & \\
\hline & \multicolumn{6}{|c|}{ Panel A: Means } \\
\hline Argentina & 0.05 & 0.0241 & 1.00 & 0.05 & 0.05 & 0.00 \\
\hline Australia & 0.00 & 0.0000 & 0.00 & 0.00 & 0.00 & . \\
\hline Canada & 0.00 & 0.0000 & 0.00 & 0.00 & 0.00 & . \\
\hline Hong Kong & 0.05 & 0.0838 & 1.00 & 0.05 & 0.00 & 0.00 \\
\hline Ireland & 0.00 & 0.0000 & 0.00 & 0.15 & 0.00 & . \\
\hline Japan & 0.00 & 0.0000 & 0.00 & 0.00 & 0.00 & . \\
\hline New Zealand & 0.00 & 0.0000 & 0.00 & 0.00 & 0.00 & . \\
\hline Norway & 0.05 & 0.0177 & 1.00 & 0.20 & 0.00 & 1.00 \\
\hline Singapore & 0.05 & 0.0169 & 1.00 & 0.00 & 0.00 & 0.00 \\
\hline Spain & 0.10 & 0.0386 & 1.00 & 0.05 & 0.05 & 0.00 \\
\hline UK & 0.00 & 0.0000 & 0.00 & 0.00 & 0.00 & . \\
\hline US & 0.00 & 0.0000 & 0.00 & 0.00 & 0.00 & . \\
\hline High Anti-director Avg & 0.0250 & 0.0151 & 0.4167 & 0.0417 & 0.0083 & 0.2000 \\
\hline Austria & 0.00 & 0.0000 & 0.00 & 0.00 & 0.10 & . \\
\hline Belgium & 0.30 & 0.4258 & 3.00 & 0.25 & 0.30 & 1.00 \\
\hline Denmark & 0.00 & 0.0000 & 0.00 & 0.05 & 0.00 & . \\
\hline Finland & 0.05 & 0.0156 & 1.00 & 0.15 & 0.00 & 0.00 \\
\hline France & 0.05 & 0.0507 & 1.00 & 0.10 & 0.05 & 1.00 \\
\hline Germany & 0.15 & 0.1304 & 1.50 & 0.10 & 0.15 & 0.67 \\
\hline Greece & 0.10 & 0.0317 & 2.00 & 0.00 & 0.00 & 0.00 \\
\hline Israel & 0.00 & 0.0000 & 0.00 & 0.05 & 0.00 & . \\
\hline Italy & 0.05 & 0.0442 & 1.00 & 0.00 & 0.00 & 0.00 \\
\hline Korea (South) & 0.00 & 0.0000 & 0.00 & 0.05 & 0.00 & . \\
\hline Mexico & 0.00 & 0.0000 & 0.00 & 0.00 & 0.00 & . \\
\hline Netherlands & 0.00 & 0.0000 & 0.00 & 0.10 & 0.00 & . \\
\hline Portugal & 0.15 & 0.1021 & 3.00 & 0.05 & 0.00 & 0.67 \\
\hline Sweden & 0.15 & 0.2074 & 3.00 & 0.10 & 0.05 & 0.33 \\
\hline Switzerland & 0.05 & 0.0077 & 1.00 & 0.00 & 0.00 & 0.00 \\
\hline Low Anti-director Avg & 0.0700 & 0.0677 & 1.1000 & 0.0667 & 0.0433 & 0.4074 \\
\hline Sample Average & 0.0500 & 0.0443 & 0.7963 & 0.0556 & 0.0278 & 0.3333 \\
\hline
\end{tabular}

Panel B: Test of Means (t-statistic) 


\section{Table 7: Probability that the Controlling Shareholder is Alone}

This table classifies countries according to their ranking in antidirector rights. We form two groups of countries: (1) High anti-directors; and (2) low anti-directors depending on whether the country's anti-director score is above the median or not. Panel A presents means for each variable using $20 \%$ as the criteria for control for a sample of the largest twenty firms (by stock market capitalization of equity at the end of 1995) in twenty-seven countries. The last column presents the country mean across all observations reported on the table. Definitions for all other variables can be found in Table 2. Panel B reports tests of means for countries above and below the median antidirector rights.

\begin{tabular}{|c|c|c|c|c|c|}
\hline Country & Family & State & $\begin{array}{l}\text { Widely Held } \\
\text { Financial }\end{array}$ & $\begin{array}{l}\text { Widely Held } \\
\text { Corporation }\end{array}$ & All \\
\hline \multicolumn{6}{|c|}{ Panel A: Means } \\
\hline Argentina & 0.85 & 0.33 & 1.00 & 0.67 & 0.75 \\
\hline Australia & 1.00 & 1.00 & . & 0.80 & 0.86 \\
\hline Canada & 1.00 & . & . & 1.00 & 1.00 \\
\hline Hong Kong & 0.86 & 0.00 & 1.00 & . & 0.81 \\
\hline Ireland & 0.00 & . & . & 0.50 & 0.25 \\
\hline Japan & 1.00 & 1.00 & . & . & 1.00 \\
\hline New Zealand & 0.80 & 0.60 & . & 0.00 & 0.50 \\
\hline Norway & 0.40 & 0.71 & 1.00 & . & 0.62 \\
\hline Singapore & 0.83 & 1.00 & 0 & 0.00 & 0.82 \\
\hline Spain & 1.00 & 1.00 & 1.00 & 0.50 & 0.92 \\
\hline UK & . & . & . & . & $\cdot$ \\
\hline US & 1.00 & & . & . & 1.00 \\
\hline High Anti-director Avg & 0.7939 & 0.7050 & 1.0000 & 0.4957 & 0.7756 \\
\hline Austria & 0.67 & 0.79 & . & . & 0.76 \\
\hline Belgium & 0.50 & 1.00 & 1.00 & . & 0.71 \\
\hline Denmark & 0.43 & 1.00 & . & . & 0.60 \\
\hline Finland & 0.00 & 1.00 & 0.00 & 1.00 & 0.73 \\
\hline France & 0.75 & 0.67 & 0.00 & . & 0.63 \\
\hline Germany & 0.50 & 0.80 & 0.33 & . & 0.60 \\
\hline Greece & 0.70 & 1.00 & 1.00 & . & 0.83 \\
\hline Israel & 0.70 & 0.63 & . & 0.00 & 0.63 \\
\hline Italy & 1.00 & 1.00 & 1.00 & 1.00 & 1.00 \\
\hline South Korea & 0.75 & 1.00 & . & 1.00 & 0.88 \\
\hline Mexico & 0.80 & $\cdot$ & . & . & 0.80 \\
\hline Netherlands & 1.00 & 1.00 & . & 1.00 & 1.00 \\
\hline Portugal & 0.56 & 0.80 & 0.67 & . & 0.65 \\
\hline Sweden & 0.50 & 1.00 & 0.00 & . & 0.43 \\
\hline Switzerland & 0.83 & . & 1.00 & . & 0.86 \\
\hline Low Anti-director Avg & 0.6457 & 0.8990 & 0.5552 & 0.8000 & 0.7396 \\
\hline \multirow[t]{2}{*}{ Sample Average } & 0.7084 & 0.8251 & 0.6921 & 0.6225 & 0.7548 \\
\hline & \multicolumn{4}{|c|}{ Panel B: Test of Means } & \\
\hline Versus Sample Mean & -0.44 & 1.11 & -0.75 & -0.93 & 0.00 \\
\hline Low vs High Anti-direct. & -1.31 & 1.27 & -2.82 & 1.27 & -0.46 \\
\hline
\end{tabular}




\section{Appendix A}

Panel A classifies the sources of ownership data for each country and gives the year of the ownership data. Panel B gives a list of books and internet resources for each country.

Panel A

\begin{tabular}{|c|c|c|c|c|c|c|c|c|c|}
\hline \multirow[b]{2}{*}{ Country } & \multicolumn{5}{|c|}{ Data Sources } & \multicolumn{4}{|c|}{ Year of Data } \\
\hline & $\begin{array}{c}\text { Primary } \\
\text { Source }\end{array}$ & Book & $\begin{array}{l}\text { Lexis / } \\
\text { Nexis }\end{array}$ & Internet & Other & $\mathrm{Yr}<95$ & $\mathrm{Yr}=95$ & $\mathrm{Yr}=96$ & $\mathrm{Yr}=97$ \\
\hline Argentina & 8 & 7 & 1 & 0 & $4^{a}$ & 1 & 7 & 7 & 5 \\
\hline Australia & 30 & 0 & 0 & 0 & 0 & 0 & 1 & 28 & 1 \\
\hline Canada & 3 & 27 & 0 & 0 & 0 & 0 & 28 & 2 & 0 \\
\hline Hong Kong & 27 & 1 & 0 & 1 & $1^{b}$ & 0 & 9 & 20 & 1 \\
\hline Ireland & 8 & 4 & 0 & 7 & $1^{c}$ & 0 & 2 & 13 & 5 \\
\hline Japan & 0 & 30 & 0 & 0 & 0 & 0 & 21 & 0 & 9 \\
\hline New Zealand & 9 & 10 & 0 & 0 & $1^{\mathrm{b}}$ & 1 & 3 & 16 & 0 \\
\hline Norway & 18 & 0 & 0 & 2 & 0 & 0 & 4 & 16 & 0 \\
\hline Singapore & 28 & 1 & 0 & 1 & 0 & 0 & 8 & 22 & 0 \\
\hline Spain & 25 & 0 & 0 & 2 & $1^{\mathrm{d}}$ & 0 & 13 & 13 & 2 \\
\hline UK & 0 & 30 & 0 & 0 & 0 & 0 & 0 & 30 & 0 \\
\hline US & 30 & 0 & 0 & 0 & 0 & 0 & 0 & 3 & 27 \\
\hline High Anti-dir & 186 & 110 & 1 & 13 & 4 & 2 & 96 & 170 & 50 \\
\hline Austria & 0 & 20 & 0 & 0 & 0 & 0 & 20 & 0 & 0 \\
\hline Belgium & 0 & 30 & 0 & 0 & 0 & 0 & 0 & 30 & 0 \\
\hline Denmark & 6 & 0 & 8 & 5 & $1^{b}$ & 4 & 5 & 5 & 6 \\
\hline Finland & 12 & 0 & 2 & 8 & 0 & 1 & 2 & 17 & 2 \\
\hline France & 20 & 0 & 0 & 10 & 0 & 3 & 17 & 7 & 3 \\
\hline Germany & 3 & 0 & 27 & 0 & 0 & 0 & 24 & 5 & 1 \\
\hline Greece & 0 & 3 & 1 & 0 & $16^{\mathrm{e}}$ & 1 & 2 & 14 & 3 \\
\hline Israel & 14 & 0 & 2 & 0 & $4^{f}$ & 1 & 6 & 12 & 1 \\
\hline Italy & 2 & 26 & 2 & 0 & 0 & 0 & 0 & 30 & 0 \\
\hline South Korea & 0 & 28 & 1 & 0 & $1^{b}$ & 4 & 1 & 23 & 2 \\
\hline Mexico & 20 & 0 & 0 & 0 & 0 & 0 & 5 & 12 & 3 \\
\hline Netherlands & 6 & 22 & 1 & 0 & $1^{\mathrm{g}}$ & 0 & 4 & 26 & 0 \\
\hline Portugal & 1 & 0 & 4 & 10 & $5^{b}$ & 1 & 8 & 9 & 2 \\
\hline Sweden & 0 & 30 & 0 & 0 & 0 & 0 & 0 & 30 & 0 \\
\hline Switzerland & 1 & 29 & 0 & 0 & 0 & 0 & 0 & 30 & 0 \\
\hline Low Anti-dir & 85 & 188 & 48 & 33 & 28 & 15 & 94 & 250 & 23 \\
\hline Sample Total & 271 & 298 & 49 & 46 & 32 & 17 & 190 & 420 & 73 \\
\hline
\end{tabular}

Notes:

a Shareholder Meeting Records.

${ }^{\mathrm{b}}$ WorldScope.

${ }^{\mathrm{c}}$ Irish Times. 
${ }^{\mathrm{d}}$ Forbes Magazine.

"Bloomberg in twelve cases; Euromoney and Euromoney in two cases each.

${ }^{f}$ WorldScope in three cases. Moodys International in one case..

${ }^{\mathrm{s}}$ Moodys International.

\section{Panel B}

\begin{tabular}{|c|c|}
\hline Country & Book / Internet Resource \\
\hline Argentina & Argentina Company Handbook 95/96. The Reference Press, Austin, Texas. \\
\hline Australia & ASX all Ordinary Index. Companies Handbook, Australian Stock Exchange, Sydney, N.S.W, 1997. \\
\hline Austria & Hoppenstedt Companies and Executives in Austria (Lexis/Nexis). \\
\hline Belgium & $\begin{array}{l}\text { Actionnariat des Sociétés Belges cotées á Bruxelles, Banque Bruxelles Lambert, Department Etudes et Stratégie, } \\
\text { June } 1996 .\end{array}$ \\
\hline Canada & $\begin{array}{l}\text { Survey of Industrials 1996, The Financial Post Datagroup, Toronto, Ontario. } \\
\text { Survey of Mines 1996, The Financial Post Datagroup, Toronto, Ontario. }\end{array}$ \\
\hline Denmark & http://www. huginonline.com/ \\
\hline Finland & $\begin{array}{l}\text { http://www.shh.fi/ffn/ } \\
\text { http://www. huginonline.com/ }\end{array}$ \\
\hline France & $\begin{array}{l}\text { French Company Handbook } 1997 \text {, The Herald Tribune, SFB-Paris Bourse. } \\
\text { http://www. bourse-de-paris.fr/bourse/sbflemett/acemet.fcgi? GB }\end{array}$ \\
\hline Germany & Hoppenstedt Aktienfuhrer 1997. Darmstadt, Germany:Hoppenstedt. \\
\hline Hong Kong & http://www.ft.com/ \\
\hline Ireland & $\begin{array}{l}\text { The Price Waterhouse Corporate Register, 1997, London: Hemmington Scott Publishing. } \\
\text { http://www.hemscott.co.ukequities/ }\end{array}$ \\
\hline Italy & Taccuino Dell'Azionista 1997, II Sole 24 Ore Radiocor, Milan, Italy. \\
\hline Japan & $\begin{array}{l}\text { Industrial Groupings in Japan, The Anatomy of the "Keiretsu",1996-1997, Tokyo, Japan: Dodwell Marketing } \\
\text { Consultants. } \\
\text { Japan Company Handbook, Spring 1997, Toyo Keizai Inc., Japan. Japan Company Handbook (Spring 1997) }\end{array}$ \\
\hline Korea (South) & $\begin{array}{l}\text { Korea Investors Service, Inc.,1990, Seul, Korea. } \\
\text { Zaebols in Korea, } 1989 \text {, Seoul, Korea: Bankers Trust Securities Research: Korea }\end{array}$ \\
\hline Netherlands & Handboek Nederlandse Beursfondsen, 1996/97, Het Financieele Dagblad/HFD Informatie, 1997. \\
\hline New Zealand & $\begin{array}{l}\text { The New Zealand Company Register, 1996, Christchurch, Mercantile Gazette Marketing. } \\
\text { http://www.nzse.co.nz/companies; }\end{array}$ \\
\hline Norway & http://www.huginonline.com/ \\
\hline Portugal & http://www.ft.com/ \\
\hline Singapore & $\begin{array}{l}\text { Stock Exchange of Singapore Ltd, Company handbook, 1996, Singapore: Stock Exchange of Singapore, } \\
\text { Research and Publications Department. }\end{array}$ \\
\hline Spain & The Maxwell Espinosa Shareholder Directory, S.P.A. Unión Editorial, Madrid, 1994. \\
\hline Sweden & $\begin{array}{l}\text { Agarna Och Makten i Sveriges Börsföretag, Dagens Nyheter, Stockholm, } 1996 . \\
\frac{\text { http://www. hupinonline.com }}{\text { http://www2.fti.se/foretag/\#i }}\end{array}$ \\
\hline Switzerland & Swiss Stock Guide, Union Bank of Switzerland, Zurich, 1996. \\
\hline UK & $\begin{array}{l}\text { The Price Waterhouse Corporate Register, 1997, London: Hemmington Scott Publishing. } \\
\text { http://www.hemscott.co.uk/equities/ }\end{array}$ \\
\hline US & http://www.sec.gov/ \\
\hline
\end{tabular}




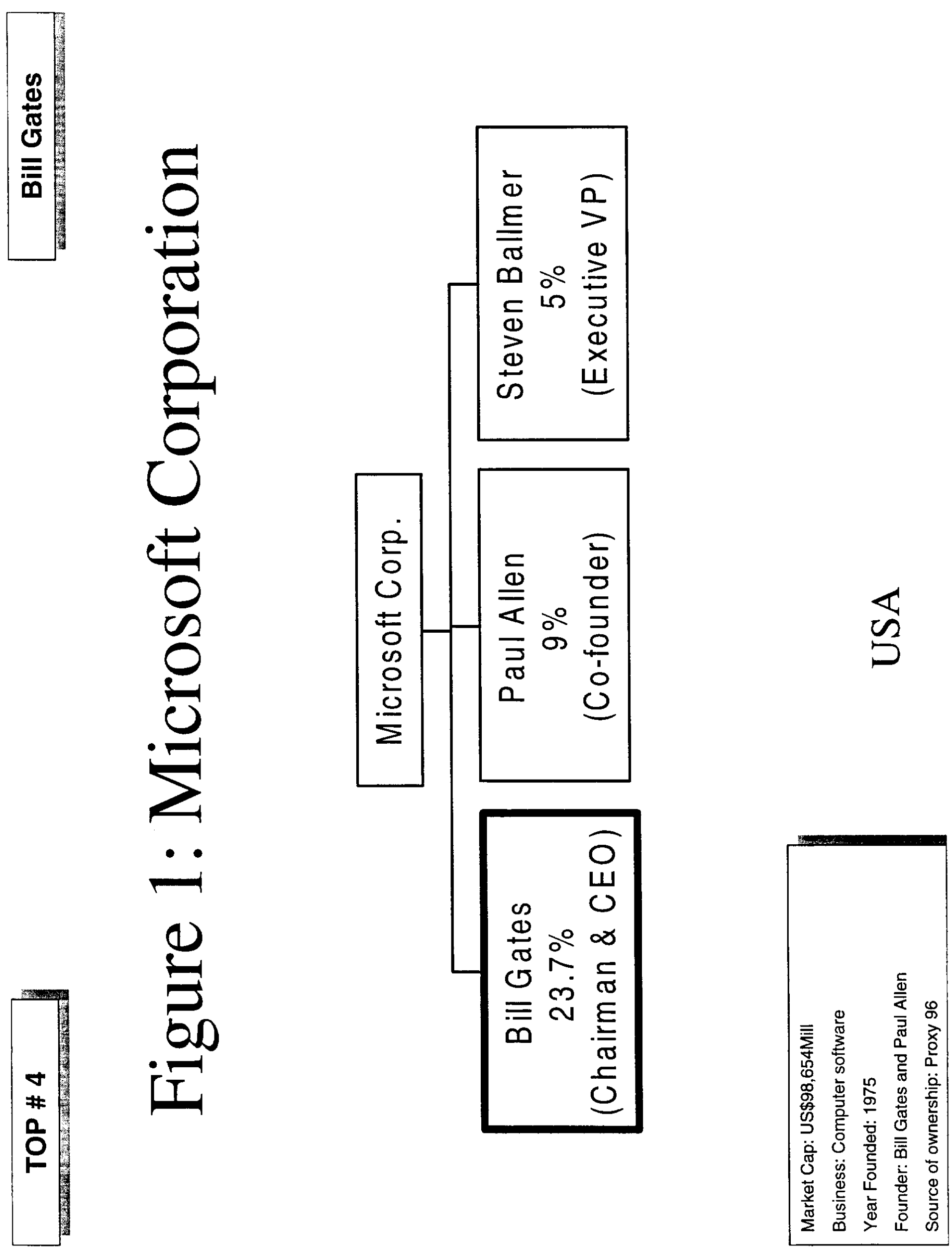




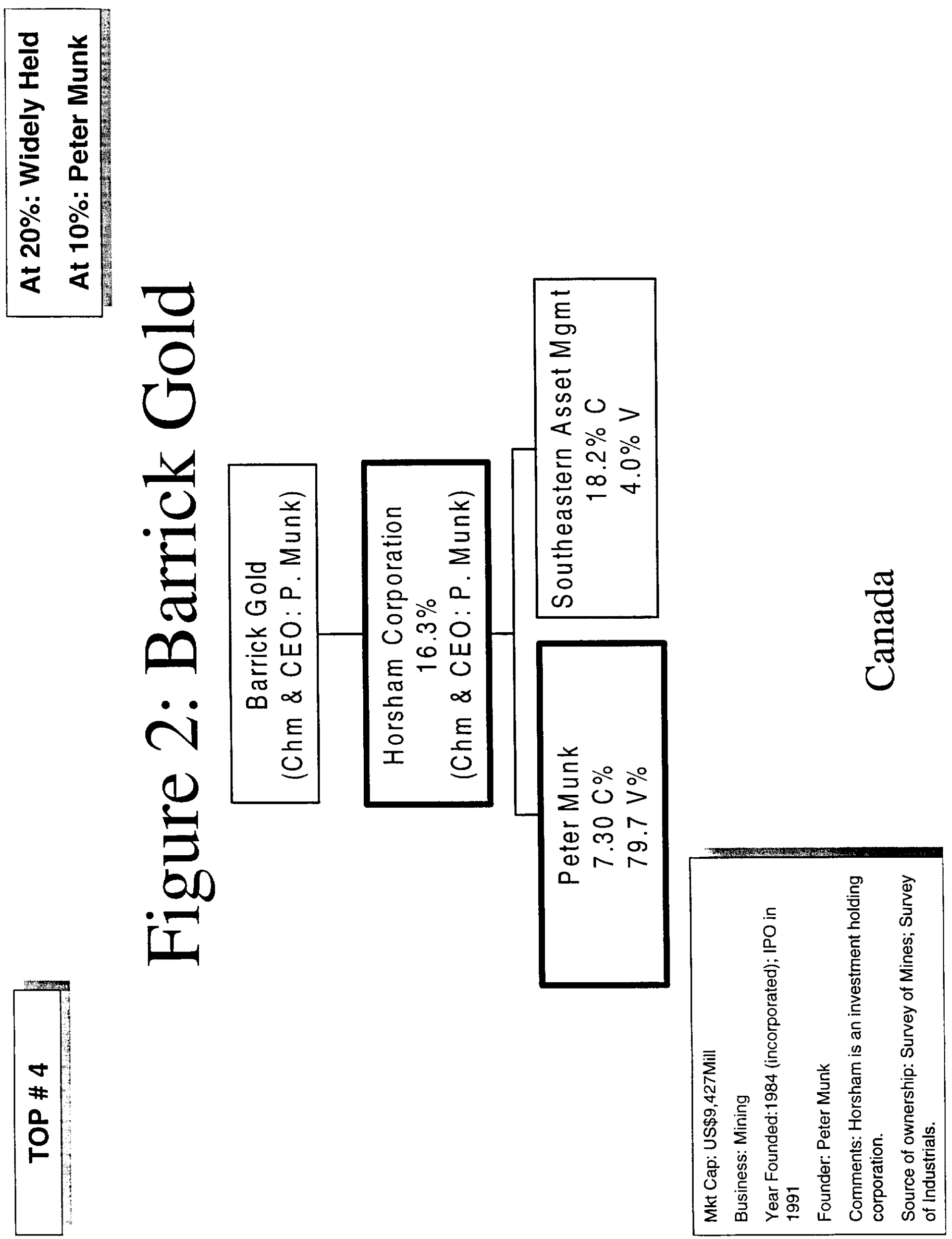




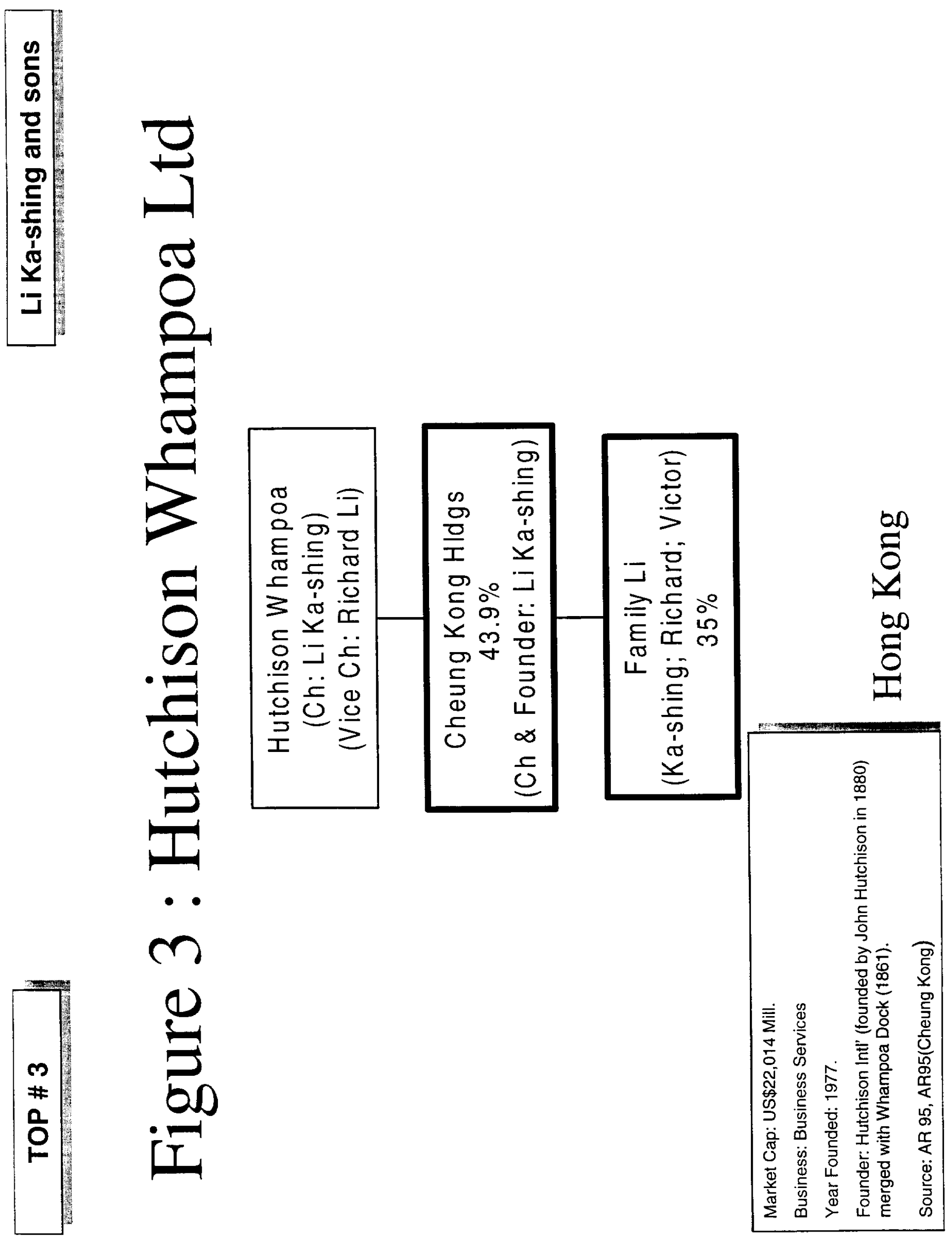




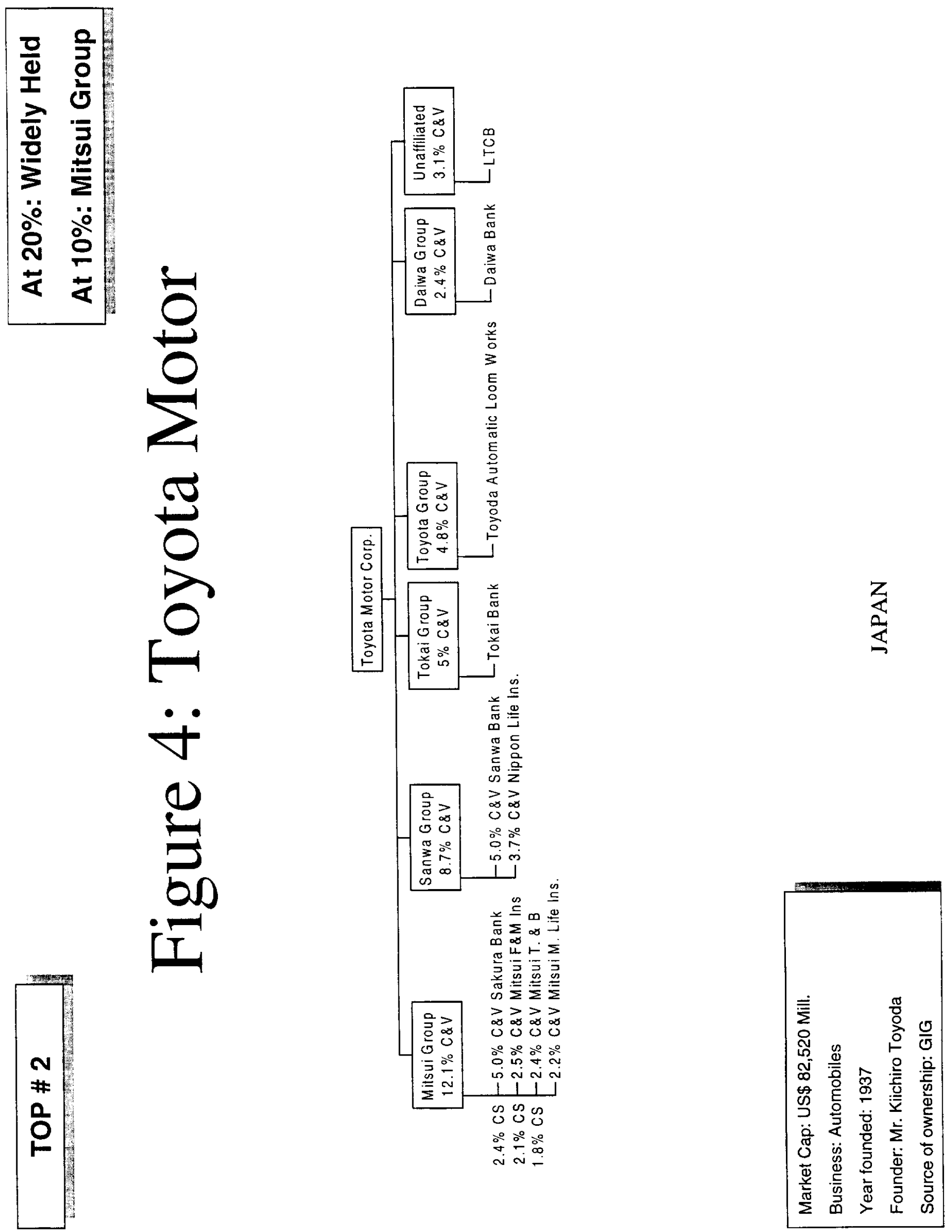




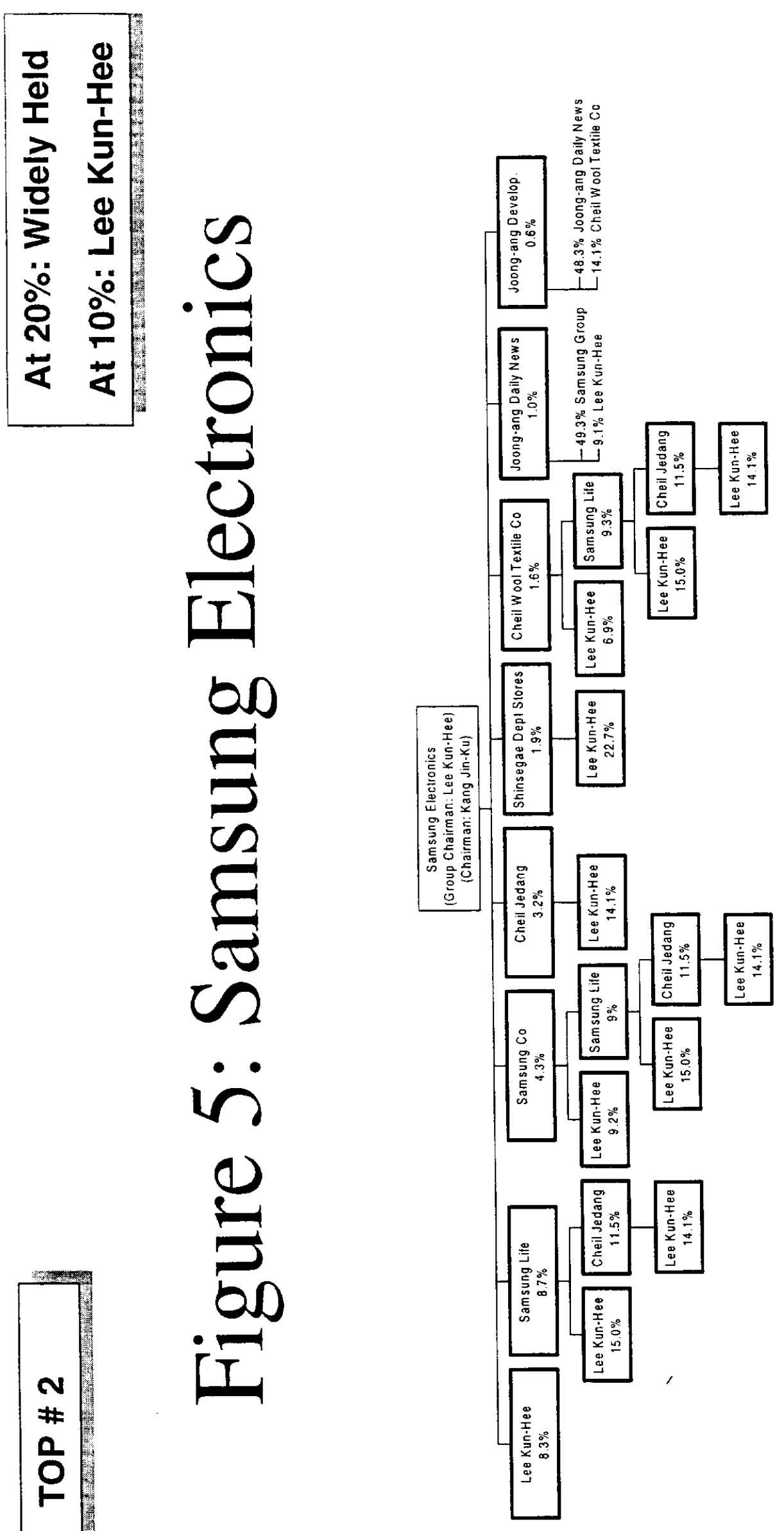

畄

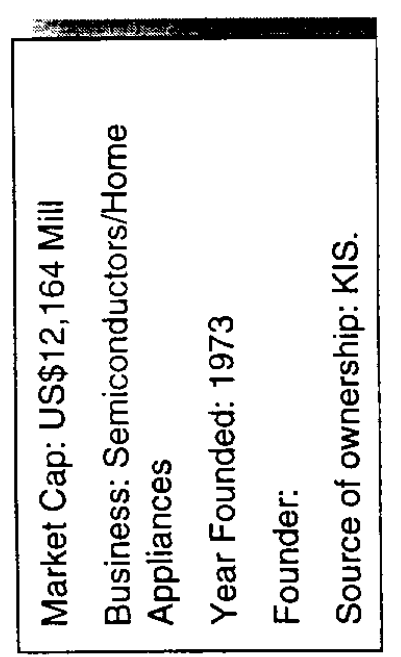




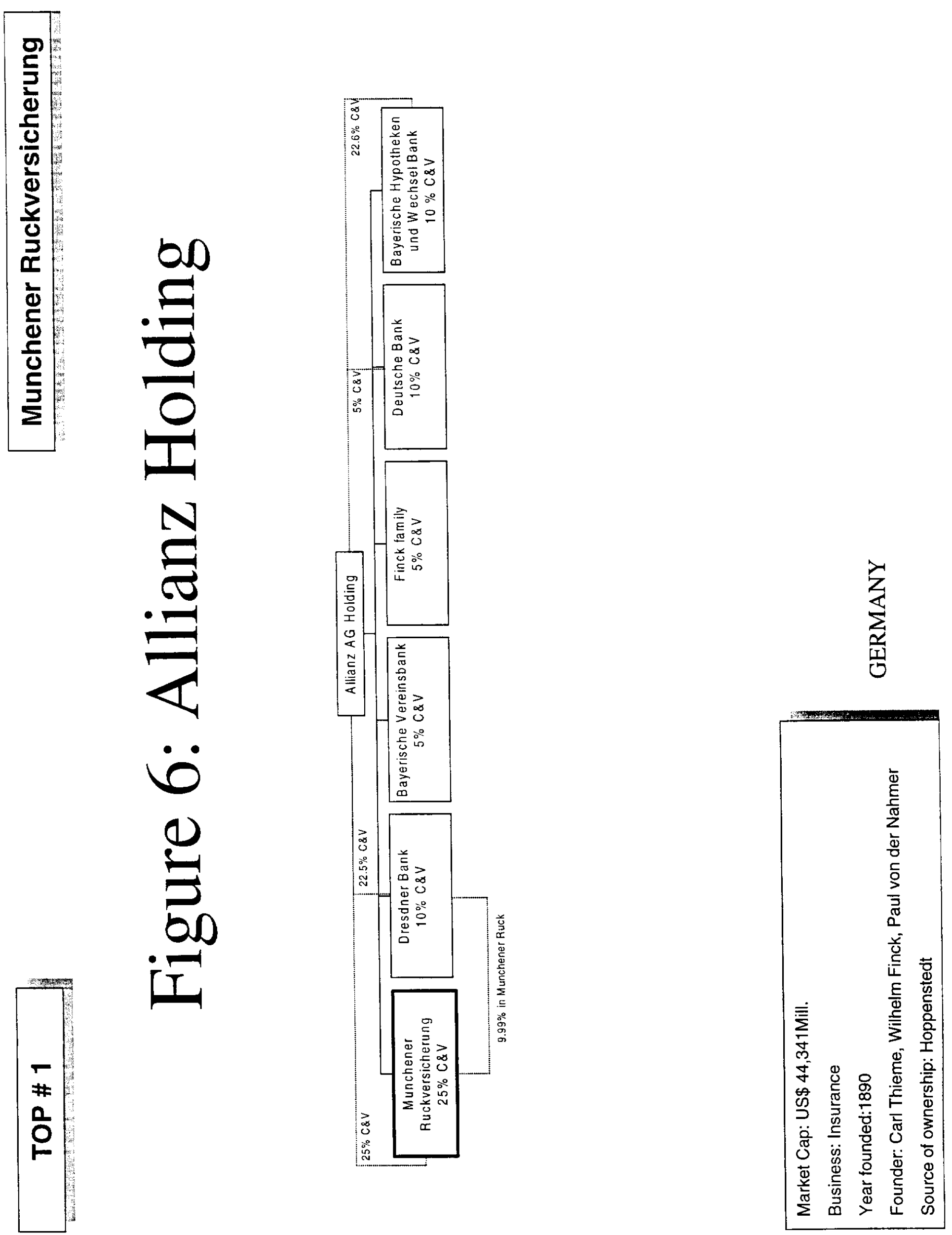



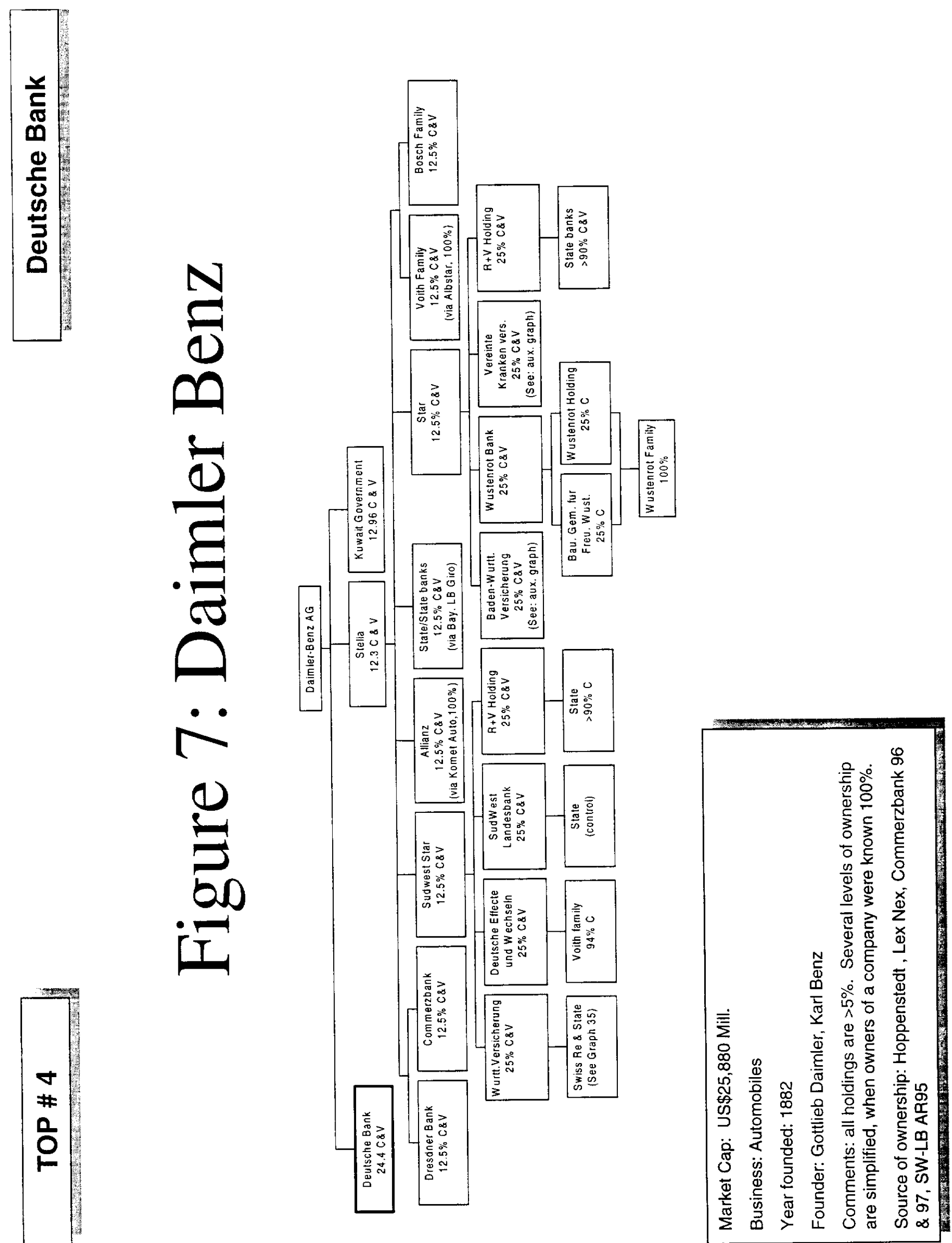

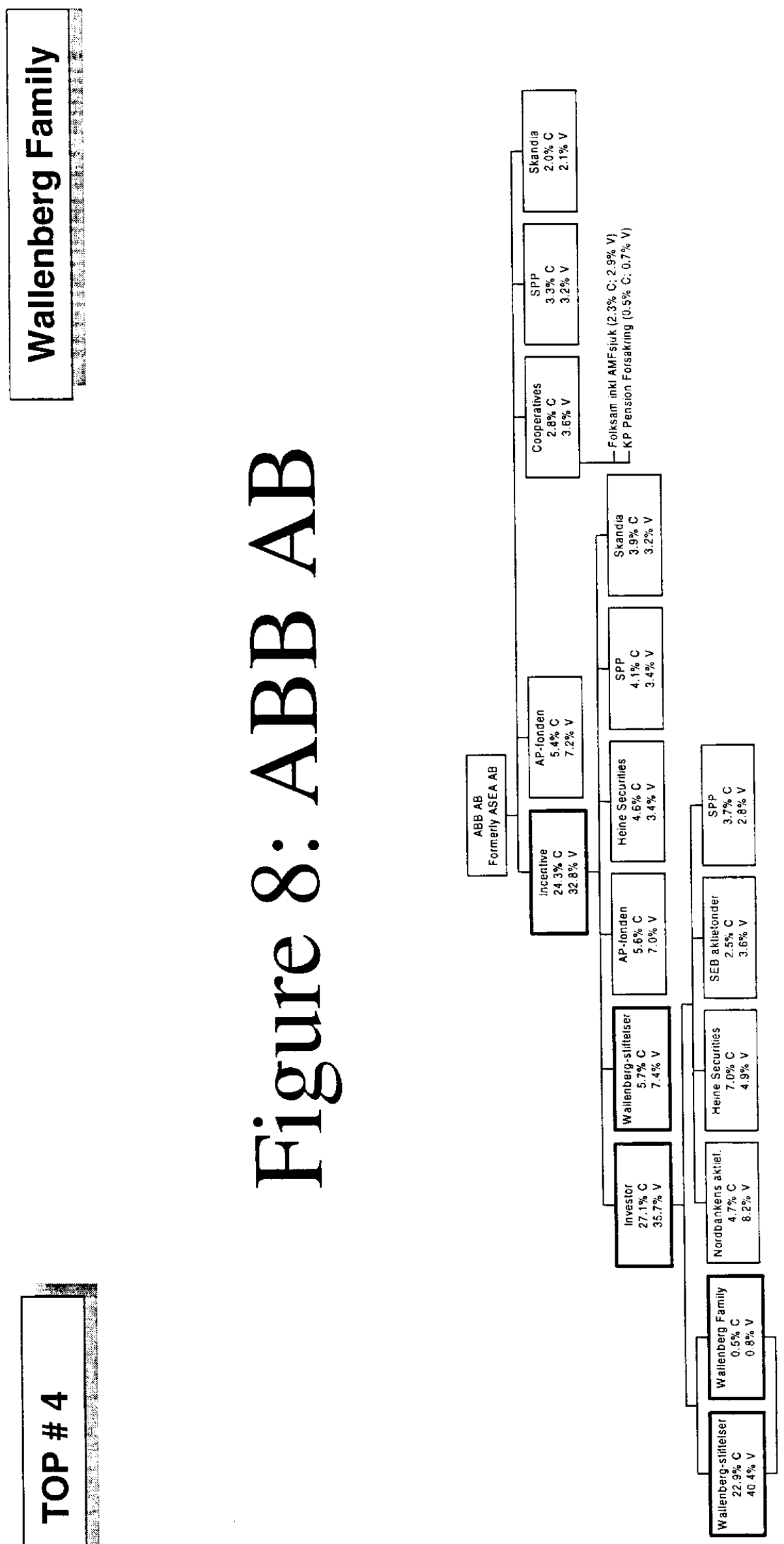

垈
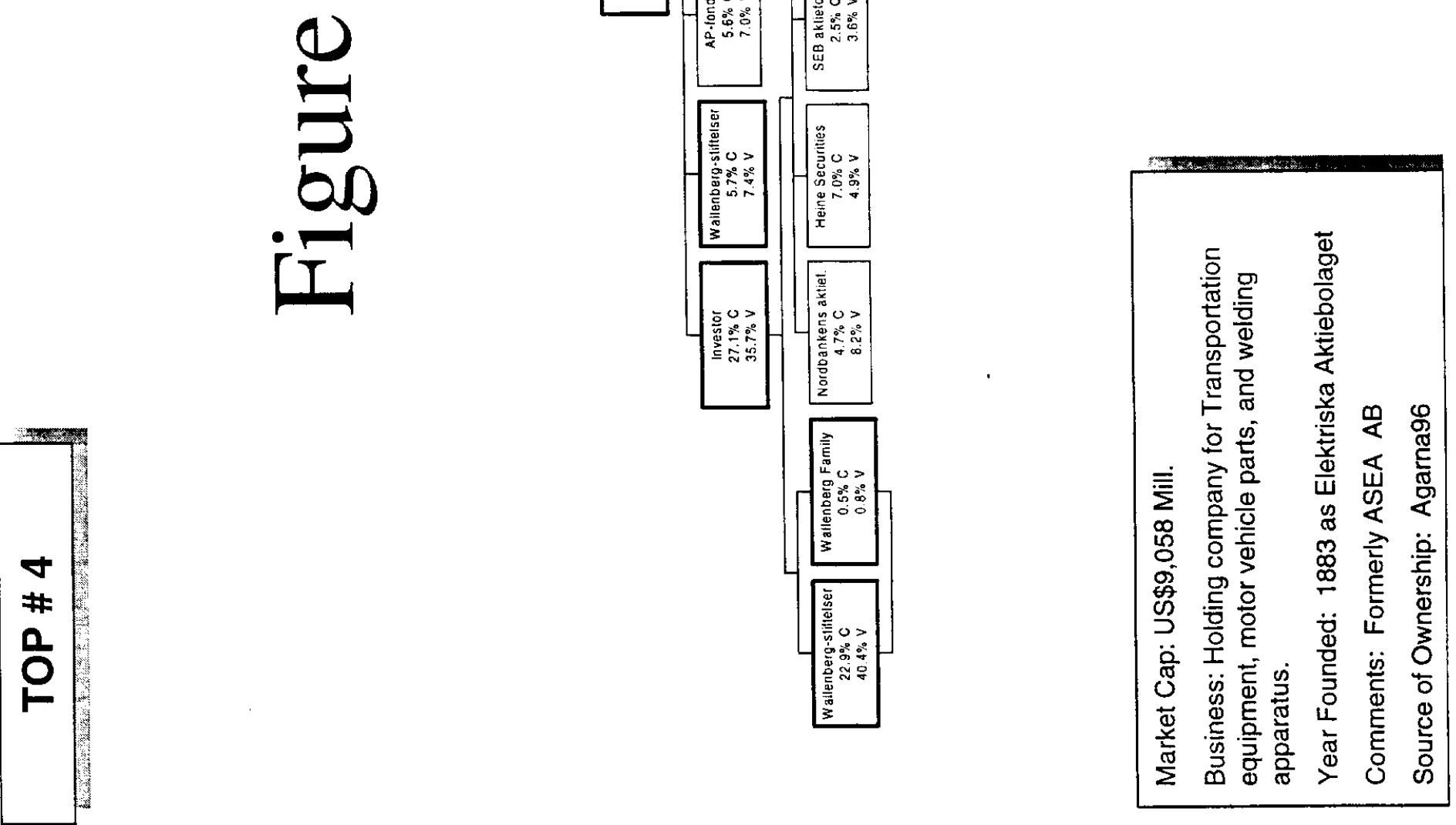

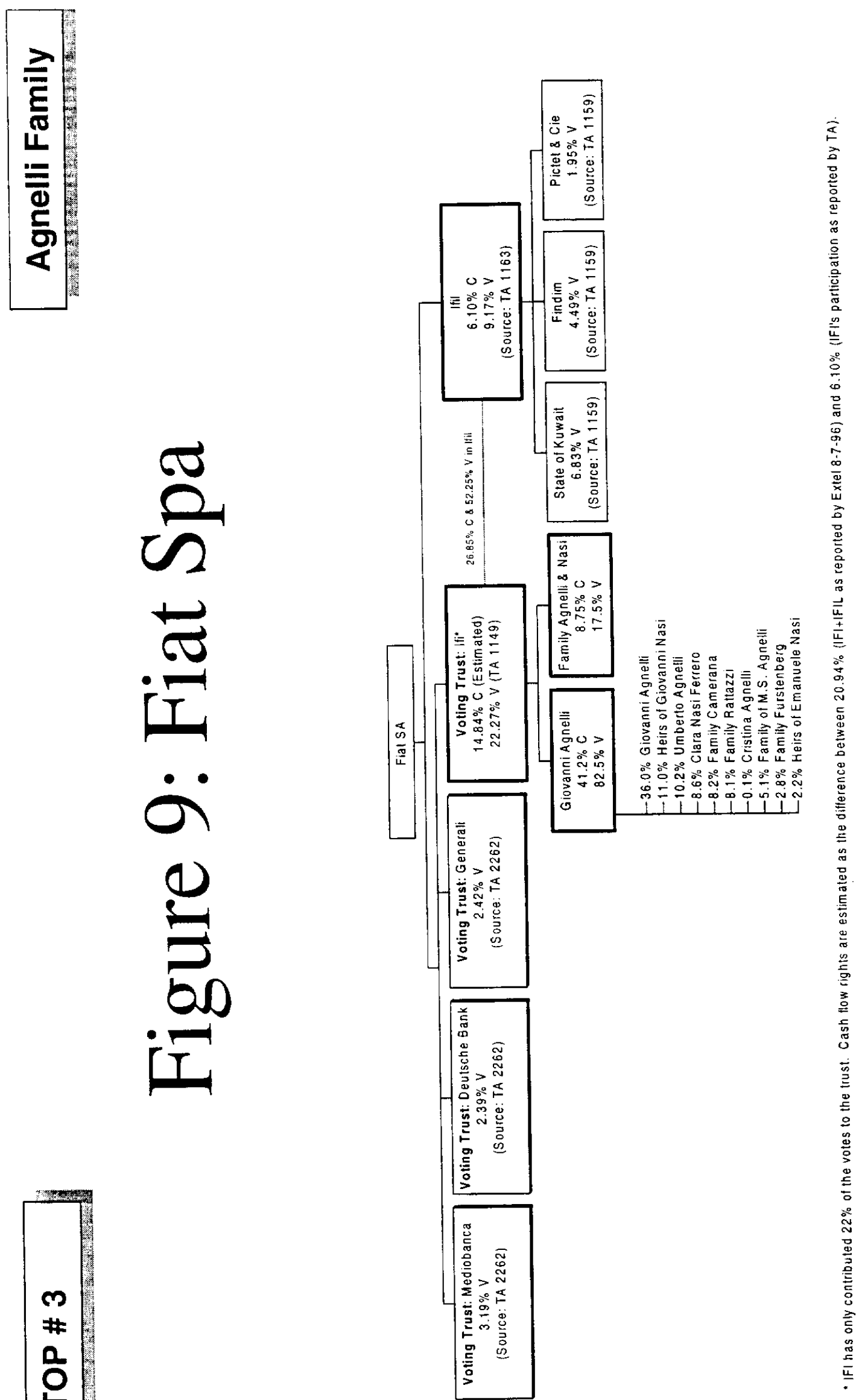

蛋
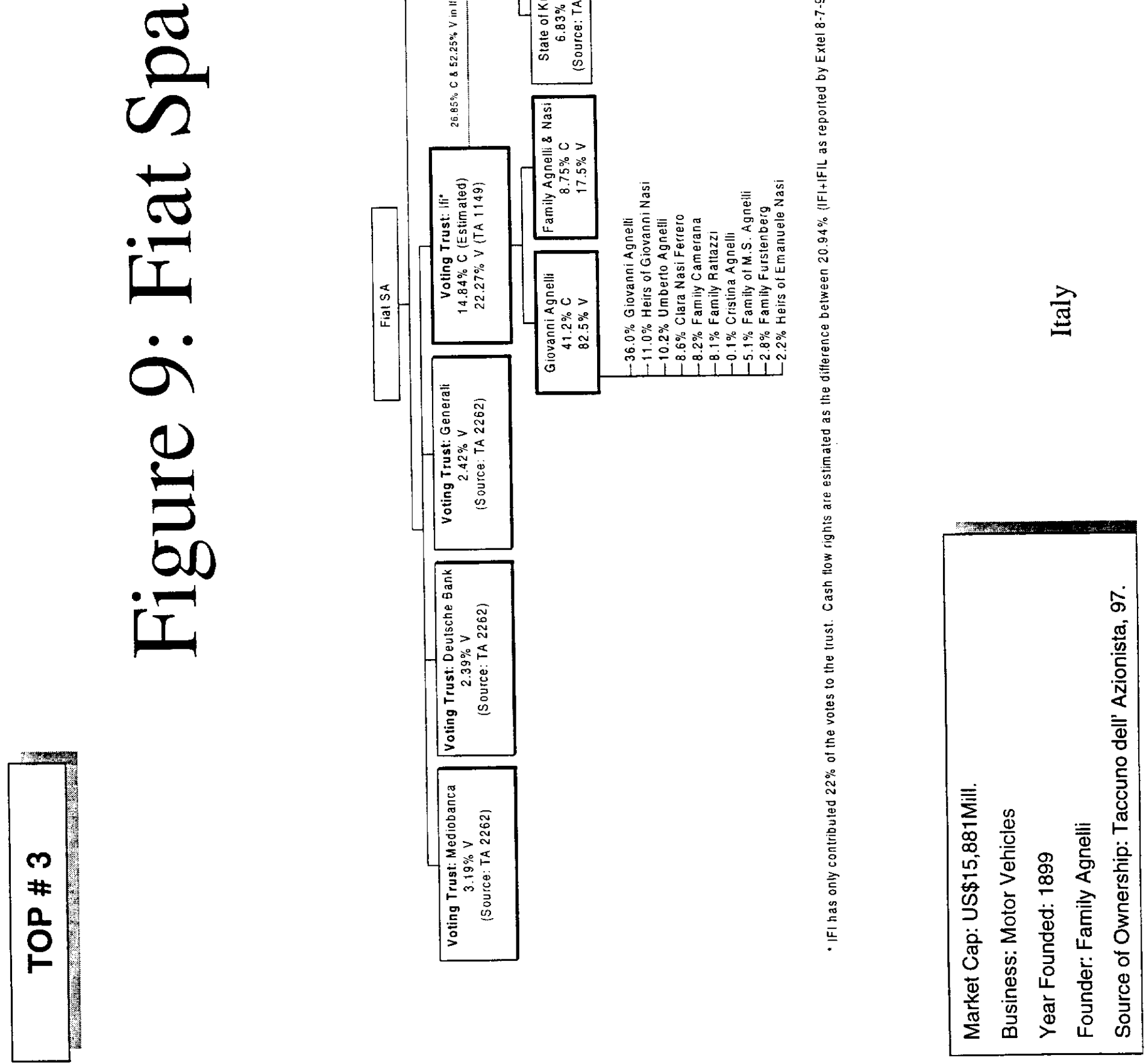


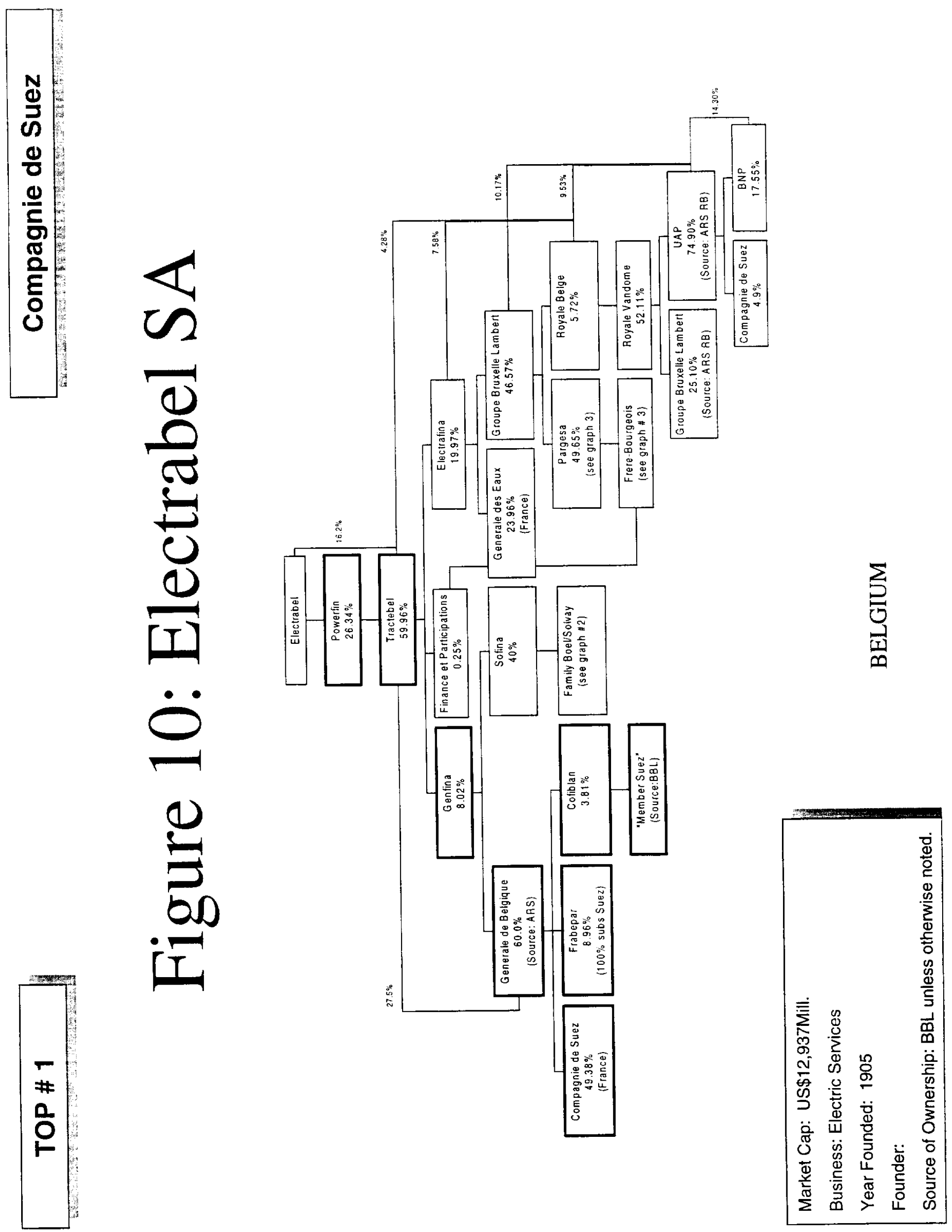

